\title{
The evolution of the avian bill as a thermoregulatory organ
}

Glenn J. Tattersall ${ }^{1, *}$, Bassel Arnaout ${ }^{1,2}$ and Matthew R.E. Symonds ${ }^{3}$

${ }^{1}$ Brock University, Department of Biological Sciences, 500 Glenridge Avenue, St.

Catharines, Ontario, Canada, L2S $3 A 1$

${ }^{2}$ Brock University, Department of Earth Sciences, 500 Glenridge Avenue, St.

Catharines, Ontario, Canada, L2S $3 A 1$

${ }^{3}$ Deakin University, School of Life and Environmental Sciences, Centre for Integrative Ecology, 221 Burwood Highway, Burwood, Victoria 3125, Australia

*Author for correspondence (E-mail: gtatters@brocku.ca; Tel.:1-905-688-5550 ext. 4815).

Accepted for Publication in Biological Reviews 1 September, 2016 


\section{ABSTRACT}

The avian bill is a textbook example of how evolution shapes morphology in response to changing environments. Bills of seed-specialist finches in particular have been the focus of intense study demonstrating how climatic fluctuations acting on food availability drive bill size and shape. The avian bill also plays an important but under-appreciated role in body temperature regulation, and therefore in energetics. Birds are endothermic and rely on numerous mechanisms for balancing internal heat production with biophysical constraints of the environment. The bill is highly vascularized and heat exchange with the environment can vary substantially, ranging from around $2 \%$ to as high as $400 \%$ of basal heat production in certain species. This heat exchange may impact how birds respond to heat stress, substitute for evaporative water loss at elevated temperatures or environments of altered water availability, or be an energetic liability at low environmental temperatures. As a result, in numerous taxa, there is evidence for a positive association between bill size and environmental temperatures, both within and among species. Therefore, bill size is both developmentally flexible and evolutionarily adaptive in response to temperature. Understanding the evolution of variation in bill size however, requires explanations of all potential mechanisms. The purpose of this review, therefore, is to promote a greater understanding of the role of temperature on shaping bill size over spatial gradients as well as developmental, seasonal, and evolutionary time scales.

Key words: birds, bill, beak, growth, character traits, temperature, developmental plasticity, phenotypic flexibility, Allen's Rule, biogeography, thermoregulation. 


\section{CONTENTS}

I. Introduction

II. Background: function, anatomy, growth, and evolution

(1) Definition and function

(2) Overview of bill anatomy

(3) Overview of bill development

(4) Growth and wear

(5) Heritability and bill size

(6) Foraging, competition and bill size

III. Bills as thermoregulatory structures

IV. Environmental contributions to variation in bill size

(1) Allen's Rule and bill size

(2) Phenotypic flexibility and appendage size

(3) Phenotypic flexibility in bill form and function

(4) Critical period in development of bills

(5) Evolutionary contributions versus phenotypic flexibility in bill morphology

(6) Seasonal changes in bill size

(7) Climate changes and bill size

$\mathrm{V}$. Heat transfer and bill size

VI. Conclusions

VII. Acknowledgements

VIII. References

\section{INTRODUCTION}

The avian bill is the archetype for how evolution shapes morphology in response to changing environments. Variation in bill morphology within and between species has been interpreted in light of differences in foraging behaviour and diet, and studies of the avian bill provide some of the most compelling evidence of the effects of food supply on a morphological trait (Badyaev et al., 2008; Benkman, 1993; Bowman, 1961; Giuliano, Griggio \& Pilastro, 2002; Herrel et al., 2005, 2010; Remsen, 1991; Smith, 1990b). Behaviours such as vocalization also contribute to the evolution of bill size (Brittan-Powell et al., 1997; Fletcher, 1988; Giraudeau et al., 2014; Hausberger, Black \& Richard, 1991; Podos \& Nowicki, 2004; Podos, Southall \& Rossi-Santos, 2004), implicating reproductive trade-offs in bill size. Indeed, extreme bill sizes, such as the large-billed toucans, were interpreted by Darwin (1871) to result from sexual selection, suggesting that bill size plays a role in sex-specific traits, such as mate selection or 
vocalization (Greenberg \& Olsen, 2010). Changes in bill size have also been associated with climate-induced changes in resource availability (Boag \& Grant, 1981), and the addition and subtraction of potentially competitive species (Grant \& Grant, 2006). Until recently, however, the importance the bill plays in physiological homeostasis has received little focus, perhaps because of an impression that the bill is a 'dead structure', being insufficiently vascularized or too small in size to be a significant area of heat exchange (Grant, 1965; Scholander, 1955, 1956; Walsberg \& King, 1978). Contrary to this perception, bills are well vascularized (Lucas \& Stettenheim, 1972), grow continuously (Matthysen, 1989), and can be significant sites for heat exchange (Hagan \& Heath, 1980; Scott et al., 2008; Tattersall, Andrade \& Abe, 2009). The role of bird bills in energetics and thermoregulation, as well as the effects of climate on geographic variation in bill size, is therefore not widely appreciated. In this review, we focus on how temperature directly or indirectly drives the evolution of bird bills through their function as thermoregulatory structures. Recent research has also uncovered a direct relationship between bill size and temperature (Greenberg et al., 2012a, b; Greenberg \& Danner, 2012; Symonds \& Tattersall, 2010), however, bill size is clearly important in foraging and social interactions (Boag \& Grant, 1981). In this context, the bill may have inherent maintenance costs, dependent on the environmental conditions. Muscles that move the bill or turbinates that occur within the upper airways at the base of the bill require a blood supply (Hughes, 1934), and this blood flow is a source of heat loss or gain for the bird. Therefore, thermoregulatory constraints may be a manifested cost of having bills selected for resource competition, particularly if they result in heat loss in cold environments or heat gain in hot environments. In addition to these potential maintenance costs, appendage growth during early life is temperature sensitive (Serrat, Williams \& Farnum, 2010; Serrat, 2013; Serrat, King \& Lovejoy, 2008) and therefore phenotypically 
flexible (Burness et al., 2013). Therefore, any evolutionary thermoregulatory selection on bill size may also be facilitated by phenotypic flexibility. The extent to which environment, nutrition, and developmental constraints interact to drive bill growth and impact energetic costs is not well understood.

Understanding the origins of variation in bill size requires explanations that consider both proximate and ultimate causes. Proximate causation relates to the mechanisms by which biological traits operate in an individual animal, while ultimate causation generally addresses why a trait evolved to address a particular function (Mayr, 1988). Ultimate causes take into account environmental factors that contribute to why an animal is able to survive and reproduce. Heritability, adaptation, and their relationship with phenotypic flexibility must be considered when assessing how a trait confers a fitness advantage (Lande, 2009; Pigliucci, Murren \& Schlichting, 2006; Price, Qvarnstrom \& Irwin, 2003; Scheiner, 1993; West-Eberhard, 2005). This review will examine the role of the bill in a thermoregulatory context, both in terms of physiological mechanisms and in an adaptive evolutionary sense. To the latter end we shall examine causal mechanisms or constraints on bill size variation by highlighting the role of environmental determinants, such as ambient climate, on bill size. The primary focus will be placed on the historical and emerging evidence of environmental factors affecting avian bill size. In addition to being selected by factors such as resource availability (Boag \& Grant, 1981) and vocalization constraints (Brittan-Powell et al., 1997; Fletcher, 1988; Hausberger et al., 1991; Podos \& Nowicki, 2004), it is hypothesized that bills are constrained by ecogeographic clines where larger bills are found in warmer climates and smaller bills in cooler climates (Snow, 1954; Symonds \& Tattersall, 2010), due to their thermoregulatory function (Greenberg et al., 2012a; Hagan \& Heath, 1980; Tattersall et al., 2009) The time scales on which these latter patterns act 
may be rapid, and occur through phenotypic flexibility, or of greater adaptive significance, manifesting in bill size patterns that conform strongly to environmental temperatures.

\section{BACKGROUND: FUNCTION, ANATOMY, GROWTH, AND EVOLUTION (1) Definition and function}

Often used interchangeably, the terms 'beak' and 'bill' are prevalent in the avian literature. In some instances, the use of the term 'bill' incorporates the entire feeding appendage including the underlying bone and the 'horny beak'; this usage would imply that beak is typically used to refer to the keratinised structure, and that bill refers to the entire structure, although this is by no means consistently applied. Whether to use the term 'beak' or 'bill' when referring to a bird's feeding appendage is a common question in the non-scientific community. Surprisingly, within the scientific community there is no consistent pattern or consensus, although approximately 2.5 times as many scientific studies used the word 'bill' compared to 'beak' in reference to 'bird or avian' studies (Web of Science, Accession Date 19 October 2015). The oldest origins of the English word 'bill' refer to the act of striking at an object, sensu stricto: 'the sparrow bitep [sic] and billetth [sic]' (Oxford English Dictionary, 2015), highlighting the utilitarian function rather than anatomical features. According to some authorities, the term bill is preferred when referring to the 'bird, platypus or dinosaur beak' (Encyclopedia Brittanica, 2014). In all cases, the feeding structure shares certain key properties: a stiff, projecting oral structure, generally lacking in teeth (Louchart \& Viriot, 2011), composed of upper and lower jaws covered by a horny sheath (ramphotheca). For the reasons outlined above, we favour the use of the word 'bill' throughout this review. 
The bill is a characteristic feature of birds, serving many essential and highly adapted functions (Van Hemert et al., 2012), and taking on a variety of forms (Fig. 1). Bills are clearly adapted to allow birds to exploit a tremendous diversity of food resources. Some species, like flamingos, possess bills which are highly specialized for one feeding method. Flamingos have a broad, downturned bill, lined with lamellae for filtering (Mascitti \& Kravetz, 2002), convergent in morphology with that of balleen whales (Olson \& Feduccia, 1980). This shape allows the birds to eat many different types of invertebrates, sifted from bodies of water. On the other hand, crows have bills which are straight and roughly conical and these birds consume a more general diet, being able to eat foods such as insects, fruits, flowers, and vertebrates (Sakai, Ralph \& Jenkins, 1989). More subtle variations in bill size or shape can be found within species, as well as among closely related species. Interpopulation comparisons of oystercatchers (Haematopus ostralegus) have shown that morphological differences in the bill are great enough significantly to change feeding techniques and food handling times (Swennen et al., 1983). In the tropical highlands of Costa Rica, hummingbird bills match the corolla depth of their favourite flowers (Wolf, Stiles \& Hainsworth, 1976). In addition to foraging, bills also serve the important functions of preening, vocalization, and thermoregulation.

\section{(2) Overview of bill anatomy}

The size and shape of the avian bill is highly variable within and among species, ranging from the powerful mandibles of a seed specialist to the precision appendages of nectar feeders; however, the basic underlying structure remains the same. Bills consist of lightweight bones that form the cores of the upper and lower mandibles (Fig. 2). Part of the inner and the complete outer surface of the bill are covered in a modified layer of cells, collectively called the 
ramphotheca (Stettenheim, 2000). Except in the flexion area of the upper bill, the ramphotheca is hard as a result of cornified cells (corneocytes) and calcium salt deposits (Bonser, 1996; Stettenheim, 2000; Van Hemert et al., 2012). The bones provide the frame for the ramphotheca and it is further shaped in individuals by local thickenings of the epidermis. Beneath the continually replaced ramphotheca lies the living epidermis, which serves to provide the ramphotheca with a constant flow of cellular material. The epidermis is made up of tightly packed keratinocytes that migrate outward as they mature, shifting from an actively growing germinative layer to a fully cornified layer (Van Hemert et al., 2012). Local thickenings of the epidermis may occur around the edge of the bill and be highly modified according to an individual's diet (Stettenheim, 2000). The dermis, a more heterogeneous layer of tissue, contains blood vessels (Fig. 2), nerve endings, and thermal and mechanoreceptors, and is located between the epidermis and the bone (Kuenzel, 2007). The dermis is highly vascularized and proportionately thickest in the tip of the bill as it replaces the premaxillary and mandibular bones in this area (Van Hemert et al., 2012). Since capillaries and blood vessels are abundant in the dermis and the dermis is proportionately thickest at the tip of the bill, the accumulation of blood vessels may serve to provide a larger proportion of nutrients to this area. On a larger scale, major arteries and veins permeate the bill itself (Fig. 3). From limited studies of vascular casts of ducks and herring gulls (Larus argentatus) (Midtgård, 1980, 1984a), the maxillary and mandibular arteries supply blood to the entire bill structure, with the maxillary artery branching into the facial and palatine arteries, the former extending superficial branches to the dorsal side of the beak. The two palatine arteries fuse together to form the medial palatine artery that extends into the upper jaw (Midtgård, 1984a). Venous return from the superficial areas of the upper beak is effected via the ethmoidal vein that connects to the opthalmic vein within a network of blood 
vessels in the region between the nasal capsule and the optic nerve (Midtgård, 1980, 1984a). In short, the bill receives blood from major cranial vessels, and the arteries and arterioles within the bill possess pre-capillary sphincters capable of varying degrees of vasoconstriction (Midtgård, 1984a). The dermis and epidermis, meanwhile, supply nutrients to the bill surface through the capillary blood vessels, facilitating ramphothecal growth. Therefore, contrary to general belief, the bill is not a dead structure, but is part of a larger network of cranial vasculature (Porter \& Witmer, 2016), and uninsulated, all of which make it a significant area of heat loss, hence implicating a vital role in thermoregulation.

\section{(3) Overview of bill development}

Avian bill size has an important role in determining thermoregulatory abilities (Greenberg et al., 2012a; Symonds \& Tattersall, 2010; Tattersall et al., 2009), and recent evidence suggests that the manner in which the bill develops constrains the variation in bill sizes and shapes (Fritz et al., 2014; Young et al., 2014). Therefore, a brief overview of the developmental origins of the bill is warranted. The embryonic avian upper bill develops from three different components that contribute to the formation of the postnatal bill, each of which will be considered in turn. All the embryonic components of the bill form from the migration and proliferation of a population of embryonic mesenchymal cells known as neural crest cells

(Gilbert, 2010; Minoux \& Rijli, 2010). Neural crest cells form after the closure of the neural tube and then disassociate from the embryonic neural ectoderm and migrate ventrally (Santagati \& Rijli, 2003). Of these migrating neural crest cells, some migrate to the facial region of the embryo, and are known as cranial neural crest cells (Minoux \& Rijli, 2010). After reaching their destination they begin to proliferate between the neural and the epidermal ectoderm, leading to 
the formation of bulges or prominences that appear in the embryonic facial region (Gilbert, 2010).

One of these prominences, the frontonasal mass, plays an important role in determining the bill size because it leads to the formation of the two major parts of the bill: the prenasal cartilage and the premaxillary bone (Lee et al., 2001). The frontonasal mass forms from the proliferation of neural crest cells by induction from the bordering epidermal region known as the frontonasal ectodermal zone that defines the dorso-ventral polarity of the upper bill (Helms \& Schneider, 2003). The frontonasal ectodermal zone contains two regions of two signalling molecules, Sonic hedgehog (Shh) and Fibroblast growth factor 8 (fgf8). These two signalling centres form a boundary between them at which cellular proliferation occurs (Helms \& Schneider, 2003). The cellular proliferation accelerates in specific regions of the frontonasal mass, known as localized growth zones, and the interaction between these zones determines the width of the bill (Wu et al., 2004). As localized growth zones are areas of high cellular proliferation they provide certain regions of the bill with many undifferentiated neural crest cells that can become cartilaginous or bony cells. Mediating the fate of the neural crest cells in the localized growth zones is the signalling molecule bone morphogenetic protein (BMP)4 that plays a role in the formation of the prenasal cartilage and consequently affects the depth and width of the bill (Abzhanov et al., 2004). Another molecule that plays a role in the formation of the prenasal cartilage is the $\mathrm{Ca}^{2+}$ binding protein calmodulin that has been shown to affect bill length (Mallarino et al., 2011). Co-developing with the prenasal cartilage and adding to its contribution to bill size is the premaxillary bone that also develops in the frontonasal mass. Determining the formation of the premaxillary bone by directing the neural crest cells to a bony fate are the transforming growth factor Tgf $\beta I I r, \beta$-catenin, and Dickkopf 3, which have been shown to affect 
the depth and the width of the bill (Mallarino et al., 2011). The two other developmental prominences that recently have been shown to play a role in constraining bill size variation through fusing with the frontonasal prominence are the two maxillary prominences and the two lateral nasal prominences (Francis-West et al., 1998; Young et al., 2014). Similarly to the frontonasal prominence, BMP4 has been shown to play a role in regulating the size of these prominences, all of which has to be tightly coordinated (Wu et al., 2006). Overall, then, bill size is readily modulated by changes in overall activity of the $B M P 4$ pathway, while its shape appears finely tuned by localized changes in the concentration, timing, and distribution of $B M P 4$ expression during early development. Little is known about the role of temperature in influencing early development of the avian bill, although slight changes $\left(36.7\right.$ versus $\left.38.9^{\circ} \mathrm{C}\right)$ in incubation temperature can lead to bill malformations in domestic birds (Noiva, Menezes \& Peleteiro, 2014), suggesting strong potential for temperature to constrain bill development.

\section{(4) Growth and wear}

Following attainment of adult size, the underlying bone ceases to grow, in what appears to be determinate growth of the skeletal structures (Greenberg, Etterson \& Danner, 2013; Matthysen, 1989). The overlying horny beak (e.g. the ramphotheca), however, undergoes continuous growth throughout life. The integument grows continually from the base of the bill, with rostrally directed growth so that there is continuous forward movement of the horny part of the bill (Kuenzel, 2007). Bonser (1996) found bill keratin to be harder than other sources of keratin from the avian integument. Bills are subject to substantial wear when feeding or foraging, particularly where the upper and lower mandibles meet, and a higher density of keratin provides some resistance (Bonser, 1996). This higher density may also protect against the abrasive effects 
of bill wiping behaviour, commonly thought to serve as a cleaning mechanism (Cuthill, Witter \& Clarke, 1992). Nevertheless, the consensus is that bill growth and abrasion tend to balance each other out, although with temporal, species, sex, or individual-specific variation contributing to dynamic changes in bill size (Green, 1981; Hulscher, 1985; Matthysen, 1989; Swennen et al., 1983; van de Pol et al., 2009). Net bill growth is assessed by measuring culmen length or bill depth in individuals over time. Determining the rate of ramphotheca growth is achieved by placing visual markers on the bill surface and tracking their progression towards the proximal tip of the bill, while abrasion rates are assessed as the difference between total culmen length changes and ramphotheca growth rates (Hulscher, 1985; Swennen et al., 1983).

The ramphotheca appears to grow primarily from the proximal half (Hulscher, 1985), presumably where cellular proliferation is most abundant, which 'pushes' the bill tissue forward towards the tip. Typically, the upper mandible grows 'over' the lower mandible, due to differential rates of tissue growth, but during the time of year of peak feeding, bill wear occurs, associated with excessive use from foraging behaviours such as digging, hammering, or sifting for food within a hardened substrate (Green, 1981). Overall seasonal variation in bill size results from the differential growth and wear (see Section IV.6). Abrasion primarily occurs at the apex of the bill since this is the region where most prey manipulation and handling occurs. One of the most well studied in terms of balance between bill growth and wear is the oystercatcher and related wading birds (Hulscher, 1985; Swennen et al., 1983; van de Pol et al., 2009). Oystercatcher bill size is variable and dynamic in size and shape, but strongly related to diet (Hulscher, 1985). Upon arrival at the spring feeding grounds, bills rapidly change from a relatively blunt to a longer and more pointed morphology as the birds sift through the wet substrate for their invertebrate prey. Furthermore, captive oystercatchers fed mussels exhibit 
higher abrasion rates than birds fed a softer, pelleted diet (Hulscher, 1985). Indirect evidence that abrasion rates relate to foraging intensity in the wild was provided by the observation that birds that lost the least mass in the wild also had higher rates of abrasion. However, an individual bird's ramphothecal growth does not appear to react to abrasion rates, which explains why external bill length measurements tend to vary as a function of foraging. Since ramphotheca growth and wear rates are similar to each other within a species but show remarkable interspecific variability, Hulscher (1985) suggested that growth and abrasion rates have coevolved. Bill growth rates in birds that experience high rates of abrasion (e.g. oystercatchers) can be up to four times higher than in birds that experience minimal rates of abrasion (e.g. pigeons), suggesting that rates are adaptive responses to nominal rates of foraging-induced abrasion. Finally, although inter-individual variation in external bill morphology is driven mostly by differences in the ramphotheca structure, interspecific differences in bill size and morphology are heavily driven by developmental changes that produce differential bone growth (Borras, Pascual \& Senar, 2000).

\section{(5) Heritability and bill size}

Intraspecific variation in bill size may be influenced by multiple sources, including how much of the variation is heritable and how much is explained by the environment, developmental variation, or epigenetic mechanisms. In a broad sense, then, heritability is the fraction of total phenotypic variation in a population that is caused by genetic differences among individuals (Pigliucci et al., 2006). A plot of mid-parent trait value versus offspring trait value is often used to determine heritability; the closer the slope of the line of best fit is to 1 , the larger the estimated heritability $\left(h^{2}\right)$ of the trait. A value of 0 would be evidence that the trait variation is due to 
variation in the environment and phenotypic flexibility is more than likely the mechanism at work. Research into bill size variation has suggested strong genetic control over bill size, primarily assessed via this estimate of heritability (Smith \& Dhondt, 1980). In the case of Darwin's finches, Keller et al. (2001) found heritability $\left(h^{2}\right)$ of morphological traits such as bill size, bill depth, bill length and body size to range from 0.5 to 0.9 , suggesting quite strong withinpopulation genetic determination. However, because the offspring and parent environments are typically similar, these may be overestimates of heritability (Grant \& Grant, 1995).

In their examination of heritability of bill size in song sparrows (Melospiza melodia), Smith \& Dhondt (1980) proposed the best way to test for parent-offspring resemblance was to exchange eggs among broods and compare the resulting offspring to their true parents and foster parents. In this study, following maturation the chicks resembled their biological parents strongly and their foster parents not at all; bill depth heritability was estimated to be 0.98 (Smith \& Dhondt, 1980). Even here, the high heritability may be an overestimate as only nest environmental effects (which include parent behaviours) were controlled for, but larger scale climatic/environmental effects were not. If the environment (i.e. temperature, rainfall) of the foster and biological parents was similar, then the variance attributable to potential environmental and flexibility components would not have been expressed, and total variances underestimated. Other issues that complicate how heritability is estimated are misidentified paternity and conspecific nest parasitism. Both scenarios involve misidentified paternity and would actually lead to an underestimate of heritability. Finally, birds tend to grow larger when they have abundant food, and yet the most plentiful feeding sites are often defended by the largest birds (Garnett, 1981); their offspring will then grow up in the same plentiful area and be large as well. Therefore, issues such as shared environments and maternal effects have 
consequences to estimates of heritability. Even maternal effects may contribute to an overestimation in that they are a form of 'environmental' variance due to differences in nutrient stores or hormonal composition of eggs (Keller et al., 2001). Consequently, while it seems apparent that bill size has a heritable component, the relative strength of this compared to environmental effects is still unclear.

\section{(6) Foraging, competition and bill size}

Any discussion of selective forces shaping avian bill size is overshadowed by studies on a single group of birds: the Galápagos Finches, or 'Darwin's Finches'. A monophyletic group (subfamily Geospizinae) containing 15 species (Sato et al., 2001), Darwin's finches are the prototypical example of an evolutionary radiation (Weiner, 1994), with species exhibiting evolutionary modifications to bill size and shape that reflect feeding specializations; this is especially pronounced in the ground finches and cactus finches, which are heavily reliant on seeds for their diet. Since Charles Darwin's early descriptions and David Lack's subsequent analysis (Lack, 1947), the finches of the Galápagos archipelago have been a fruitful study system into the rapid potential for evolutionary changes in avian bill morphology. Indeed, numerous fundamental evolutionary processes have been documented through the study of bill morphology (Boag \& Grant, 1981; Grant \& Grant, 1995, 2000, 2002a, b, 2005, 2006; Price et al., 1984; Schluter, Price \& Grant, 1985). It is now widely accepted that much of the remarkable variation seen in finch bills is reflected in the foods they eat. Birds with large bills are able to crack larger seeds, while birds with smaller beaks are more efficient at exploiting smaller, softer seeds (Herrel et al., 2009; van der Meij \& Bout, 2008). Foraging and resource availability also play a major role in bill size in other species of birds (Benkman, 1987; Smith, 1990a, b). In cases where 
food is abundant, however, a different set of selection pressures is likely in operation (Boag \& Grant, 1981), just as in cases of ecological release (Greenberg \& Danner, 2013; Luther \& Greenberg, 2014), where reduced competition and widening of niche partitioning relaxes selection pressures, and reveals strong environmental (i.e. thermal) determinants of bill size and morphology. Indeed, Grant \& Grant (1993) demonstrated how climatic events can lead to significant changes in bill dimensions, although the direct involvement of environmental factors on the changes in bill size was not considered. Therefore, the broader applicability of resource acquisition driving avian bill sizes in more complex environments is likely to be dependent on other factors, including climatic variables such as temperature, humidity, or water availability.

\section{BILLS AS THERMOREGULATORY STRUCTURES}

The evolution of birds has been shaped by a tremendous variety of factors. Birds are endotherms, and are therefore capable of sustaining elevated body temperatures through the actions of their elevated metabolism (Angilletta et al., 2010; Tattersall et al., 2012; Ward \& Slater, 2005; Yarbrough, 1971). To aid in this process, birds have evolved several different mechanisms of thermoregulation (Hafez, 1964). These mechanisms include panting, bathing, microsite selection, ptilo-erection, and using heterothermy to avoid mismatches between energy supply and demand (Hafez, 1964). Nevertheless, thermoregulation is a process involving the whole organism, and it is challenging to assign exclusive thermoregulatory function to any specific organ like one might ascribe to the heart or the lung as organs of the cardiovascular and respiratory systems. Until recently, the form and function of the bill have mostly been considered as adaptations related to different feeding strategies; however, evidence accruing over the past few years suggests that birds may also be able to use their bill to conserve or dissipate body heat, 
depending on the environmental conditions (Burness et al., 2013; Greenberg et al., 2012a; Hagan \& Heath, 1980; Tattersall et al., 2009; Tattersall \& Cadena, 2010).

The avian bill is a viable candidate for a role in thermoregulation since it is highly vascularized but poorly insulated (i.e. a potent thermal radiator). Blood flow is supported beneath the horny ramphotheca by a network of blood vessels (Stettenheim, 2000). The surface area of most bills are small compared to total body surface area, however, bills contribute significantly to the total un-insulated surface area of a bird (Greenberg et al., 2012a). There are a number of recent studies which have provided evidence for the bill being employed in thermoregulation. One of the first studies on this subject involved Pekin ducks (Anas platyrhynchos) and showed that bill surface temperatures can change dramatically with ambient temperature (Hagan \& Heath, 1980). In cold environments, the surface of the duck's bill became cool, and the base of the bill was kept warmer than the tip. In very warm environments, the surface temperature of the bill was more variable. Small regions on the surface of the bill would heat up, then cool down in only a few minutes, indicating high levels of rapidly changing blood flow to the bill (Hagan \& Heath, 1980). This experiment shows that the ducks were able to change the blood flow within their beaks in response to environmental temperature variation, which in turn would change their ability to lose heat to the environment through radiation and conduction from the bill (Hagan \& Heath, 1980). The removal of body heat through vasculature in the bill is likely to be especially efficient, as in most birds it is the only body part, aside from the feet and legs, which is featherless and exposed to the environment.

One test of the thermal radiator hypothesis for avian bills is to examine how its function has evolved. Scott et al. (2008) examined low oxygen (i.e. hypoxia) tolerance and bill vascular recruitment in three species of waterfowl with different reliance on high-altitude flying. A 
common response to brief low-oxygen exposure in many endotherms is rapidly to adopt a controlled reduction in body temperature (Tattersall \& Milsom, 2009), which is often accompanied by a transient 'dumping' of core body heat through a thermal window, or noninsulated surface, such as the bill or feet (Tattersall \& Milsom, 2003). Greater reliance on thermal windows would indicate a more profound lowering of body temperature in response to hypoxia, and be indicative of a controlled body-temperature reduction strategy over a hypoxia tolerance strategy. The bar-headed goose (Anser indicus) is known for its migratory flights within and through the passes of the Himalayas, achieving powered flight at altitudes of over $6000 \mathrm{~m}$ (Scott et al., 2015), whereas the related greylag goose (Anser anser) and outgroup Pekin duck are low-altitude waterfowl. The bar-headed goose possesses genetic and physiological adaptations that allow it to fly in low-oxygen conditions (Scott et al., 2015). When compared under simulated high-altitude conditions, the bar-headed geese showed less usage of the bill as a thermal radiator, only adopting this strategy at extreme levels of hypoxia compared to the greylag goose and Pekin ducks which showed extremely high recruitment of the bill vasculature to assist in lowering body temperature. These bill vasomotory adjustments were dynamic both across species as well as within species (Fig. 4), with bill surface temperatures changing dramatically within seconds, indicating extensive neurophysiological control of blood supply, a feature critical to thermoregulatory control.

An extreme example of the avian bill as a thermal radiator was demonstrated by Tattersall et al. (2009). The toco toucan (Ramphastos toco) bill is extremely large relative to body size, at nearly $40 \%$ of the total body surface area. Adult toucans vasodilate the blood vessels beneath the ramphotheca when temperatures rise above the thermal neutral zone and constrict blood flow when below the thermal neutral zone to conserve metabolic heat; as a 
consequence, $30-60 \%$ of total heat loss at rest can be accounted for by the bill, with maximum values of heat loss rising above $400 \%$ of resting heat production. These high estimates of heat exchange belie the transient nature of the underlying blood flow, since thermal balance could not be maintained if blood flow was constantly elevated. Tattersall et al. (2009) also suggested a possible explanation for the advantage of the bill as a thermal organ over other uninsulated appendages (i.e. limbs) lies in its vascular arrangement. In a normal avian limb, blood flows in a counter current manner, with heat from arterial blood recovered by the veins without the need for vasoconstriction (Steen \& Steen, 1965). In counter-current limb heat exchange, warm blood flows through the arteries from the core of the body to the ends of limbs. The heat from this blood warms nearby veins and is transferred back from the extremities to the core of the body (Ederstrom \& Brumleve, 1964; Midtgård, 1981; Millard \& Reite, 1970; Steen \& Steen, 1965), preventing heat loss to the environment through the legs and feet. To date no evidence suggests that any avian bills possess counter-current heat exchange and therefore a more random vascular arrangement would preclude or minimise their capacity for heat conservation relative to the limbs. As the poorly insulated bill has been proven an asset for dumping heat in a warm environment, it may simultaneously function as a liability in a cold environment (Symonds \& Tattersall, 2010). Although vasoconstriction to the bill would still conserve heat, it would also serve to starve the bill tissue of blood flow, so it is likely that a trade-off exists in the level of vasoconstriction of blood flow to the bird bill at low air temperatures, with the net result that low but constant levels of heat loss always occur across the bill. These effects are not restricted to large-billed birds like the toucan. It is common for birds to tuck their bills between or under their wings while sleeping, presumably to aid in heat conservation (Reebs, 1986; Tattersall et al., 2009; Wellmann \& Downs, 2009). 
Understandably, based on surface area alone, birds with relatively large bills would be expected to exhibit considerable heat exchange capacity; however, even the smaller bills of passerines appear to play a role in thermal homeostasis. In a study on two subspecies of song sparrows with different bill sizes, Greenberg et al. (2012a) estimated heat loss from the bill and limbs at a range of different ambient temperatures and found that the subspecies with the larger bills would exchange significantly more heat through their bills regardless of ambient temperature. This augmented heat exchange was only partly due to bill size differences, implying a functional association between the forces driving bill size and bill thermal radiator function. We posit that when bill size co-varies with thermal radiator function, bills may be considered as thermoregulatory exaptations sensu stricto (Gould \& Vrba, 1982).

One well-known example of a thermoregulatory exaptation is in the legs of birds (Arad, Midtgard \& Bernstein, 1989; Midtgård, 1981). While clearly adapted for locomotion, the legs of birds have dense networks of veins and arteries arranged in a non-random manner which facilitates counter-current heat exchange (Arad et al., 1989; Midtgård, 1981). Interestingly, the fact that bird legs are unfeathered is also likely related to another method of limb-based thermoregulation, involving vascular retes and shunt vessels, called anastomoses that bypass the capillary bed between arteries and veins. These anastomoses are much larger in diameter than capillaries, which allows for much larger amounts of blood flow to reach the periphery, thereby facilitating convective heat transfer from the core of the body to the periphery. In some species, the legs are very important for heat dissipation in warm climates and during flight (Baudinette et al., 1976; Johansen \& Bech, 1983; Johansen \& Millard, 1973; Maloney \& Dawson, 1994; Martineau \& Larochelle, 1988). For an emu (Dromaius novaehollandae), heat loss through the legs can account for almost $40 \%$ of total body heat loss at rest (Maloney \& Dawson, 1994). In 
pigeons (Columba livia), heat loss through the legs is a large part of overall heat loss, especially during flight (Martineau \& Larochelle, 1988). When a pigeon's legs are exposed to moving air

they are able rapidly to decrease their deep cloacal temperatures from values attained during flight (Maloney \& Dawson, 1994). The vascularization needed to supply the leg with energy for movement could have been selected for improved thermoregulatory abilities in the face of thermal stress.

Analogous non-avian examples of thermoregulatory exaptations have been described previously; ungulate horns are well vascularized, and have been shown to be involved in thermoregulation (Cain et al., 2006; Picard et al., 1994; Taylor, 1966). Goat horns have an extensive network of blood vessels, which are able to vasoconstrict and vasodilate in response to cold or hot environmental conditions, respectively (Taylor, 1966). Additionally, after exercise, up to $12 \%$ of total body heat loss occurs through the horns (Taylor, 1966), which could help prevent hyperthermia after exertion in warm climates; this exertion could result from any activity, including mate competition or regular activities. In summary, since homeostatic control of body temperature can take advantage of any physical transfer of thermal energy, numerous organs and structures may turn out to be thermoregulatory exaptations, and at minimum the influence of the thermal environment should be considered in any size-based adaptive assessment of function.

\section{ENVIRONMENTAL CONTRIBUTIONS TO VARIATION IN BILL SIZE}

\section{(1) Allen's Rule and bill size}

Ecogeographical rules relate large-scale geographical distributions to morphological variation and offer the potential to describe how animals may be restricted to the environmental 
conditions under which they persist (Mayr, 1956; Olson et al., 2009). One prominent parameter that varies systematically across large geographic regions is temperature, and Allen (1877) observed over 100 years ago that appendages are shorter in endotherms from colder climates, leading to 'Allen's Rule' (Allen, 1877). Clinal variation in appendage size is argued to exist for reasons related to thermoregulatory efficiency afforded by differences in the surface area to volume ratio; large appendages lose heat more effectively in warm environments. Tails, ears, limbs and bills in endotherms function as specific areas for enhanced heat exchange with the environment as they usually have little to no insulative properties (Cartar \& Morrison, 2005; Demicka \& Caputa, 1993a; Fooden \& Albrecht, 1999; Raman, Roberts \& Vanhuyse, 1983; Stevenson, 1986; Symonds \& Tattersall, 2010). The progressive shortening of extremities in the cold is regularly viewed as a genetically determined thermoregulatory adaptation (Allen, 1877), however, several experiments have shown that adjusting ambient rearing temperatures of mammals can modify phenotype and alter extremity length (Al-Hilli \& Wright, 1983; Demicka \& Caputa, 1993b). Recently, it has also been shown that after accounting for genetic and environmental components, one possible reason for difference in body form under different temperatures may be post-embryonic ontogenetic plasticity (Serrat et al., 2008).

To date, most research into Allen's rule has focused on limbs, tails, or ears, and primarily in mammals (Fooden \& Albrecht, 1999; Mayr, 1956; Nudds \& Oswald, 2007; Scholander, 1955; Stevenson, 1986). In terms of birds, however, there has been less effort to examine Allen's rule, possibly because of an impression that their high mobility (e.g. migration) would mitigate many of the potential climatic effects on morphology. However, the size of any heat exchange organ may be under selection in relation to a particular thermal environment. Therefore, if Allen's rule holds, species at higher latitudes or altitudes (i.e. colder environments) should have relatively 
smaller bills as a means to conserve heat. Despite the lack of research focus on this topic in avian bills, considerable evidence exists from descriptions of intraspecific variation that many bird species do display geographic patterns in bill size that can be interpreted in light of climatic variables like temperature or water availability. Table 1 provides a list of studies where intraspecific variation in bill size has been documented in the context of latitude or climate, indicating where patterns conform to the thermoregulatory trend outlined according to Allen's rule. The list comprises 110 bird species or populations, although is unlikely to be comprehensive since many studies only report this information coincidentally to other research questions. Of these, $64(58 \%)$ demonstrate the pattern predicted by Allen's rule (smaller bills at higher latitudes/altitudes and cooler climates). For another 10 studies which do not appear to show Allen's rule in relation to bills, the pattern is potentially confounded by lack of body size data. Climate selecting for smaller-sized individuals in warm climates (Bergmann's rule) might also indirectly select for smaller bills in absolute terms, but larger bills in relative terms. Consequently, our survey suggests that, while not ubiquitous, climate-related geographic clines in bill size are likely to be the norm for many bird species.

Such intraspecific variation might be due to adaptation and selection, but equally could be the result of phenotypic flexibility to warm environments. Interspecific studies however, would be more suggestive of an evolutionary basis to this geographic variation in bill size. To this end, Symonds \& Tattersall (2010) undertook a phylogenetic comparative analysis of bill length across 214 species across eight families of birds. Bill sizes were standardised relative to body size, since bill size scales closely with body size, and metabolic heat production and loss is also a function of body mass. Once body size and phylogeny were taken into consideration, a significant relationship in support of Allen's Rule was found in all but one of the eight 
taxonomic groups analysed, the Australian estrildid finches (Fig. 5). Bill lengths were typically smaller in species found at higher latitudes or elevations in all other groups. A possible evolutionary explanation, in agreement with Allen's rule, is that thermoregulatory costs of larger bills become extreme in colder environments. Conversely, it may be that there is selection for large bills in warm environments, in order to assist with the dumping of excess heat loads, thereby minimizing thermal stress (Greenberg et al., 2012b; Tattersall et al., 2009). Subsequent research by Greenberg et al. (2012b) suggests that variation in bill size in song sparrows is more strongly tied to maximum summer temperatures, suggesting that augmentation of heat loss is under selection in these species (see Section IV.6). Whilst it is possible that there is geographical variation in bill size for other reasons such as resource exploitation or sexual selection that constrains the distribution of birds with larger bills to warmer environments, the consistency of the pattern across such diverse species, from piscivorous penguins, to granivorous parrots, to omnivorous toucans strongly suggests a thermoregulatory adaptation, not one related to diet or reproduction (Symonds \& Tattersall, 2010). Although the estrildid finches did not inhabit a wide range of temperatures (Symonds \& Tattersall, 2010), the lack of relationship may be attributed to costs in exhibiting temperature-dependent bill sizes in seed-cracking birds, where dependency on resource handling is important. Further, Mayr (1970) suggested that exceptions to Allen's rule would occur in smaller-sized birds where there may be constraints on how small the bill can be and still remain functional (i.e. incapable of handling available food). Symonds \& Tattersall's (2010) results support this argument given that estrildid finches were the only group that showed no correlation between bill length and body size.

Nudds \& Oswald (2007) demonstrated that limb size of numerous seabird species was strongly associated with temperature of breeding habitat, providing convincing interspecific 
evidence for the adaptive value of Allen's Rule. It is noteworthy, therefore, that when Symonds \& Tattersall (2010) found evidence for Allen's Rule in a wider array of bird taxa, bill size was always more strongly associated with habitat temperature than limb size. We suggest that this result may be partially explained by constraints that blood vessel architecture imposes on any potential thermoregulatory efficiency. Bird limbs are iconic for their counter-current artery-vein arrangement that bestows maximal efficiency of heat retention in the cold. Given the networkstyle vasculature supplying the bill surface, it is unlikely that bills are able completely to negate heat exchange to the environment in the cold, which supports the stronger trend in bill size with temperature.

\section{(2) Phenotypic flexibility and appendage size}

Adult character traits associated with environmental variables are the product of both genetic and environmental sources of variation. Dynamic phenotypes (i.e. physiological, behavioural) have long been studied in this regard, with physiological traits demonstrating evidence of thermal acclimation and seasonal acclimatisation (Tattersall et al., 2012). The role of phenotypic flexibility (Piersma \& Drent, 2003) in morphological variation is more contentious (Travis, 1994). We use the term 'flexibility' based on Piersma \& Drent's (2003) definition to refer to any change in an organism's behaviour, morphology, or physiology in response to its environment that is generally reversible (Debat \& David, 2001; Fordyce, 2006). Such flexibility

allows for a single genotype to produce a variety of phenotypes (i.e. reaction norms; Pigliucci et al., 2006; Travis, 1994), and contributes to observed morphological variation, especially in species with wide geographic ranges. Therefore, the spectrum of an organism's potential phenotypic responses is made possible by the combination of its genotype and surrounding 
environment (Debat \& David, 2001). Geographical variation in trait phenotype is often assumed to be due to genetic factors, and that a change in phenotype is due to natural selection acting on genes, however, if environmental gradients exist within a species' geographic range, phenotypic flexibility cannot be assumed to be absent (Kinnard \& Westneat, 2009; Kunz \& Ekman, 2000; Price et al., 2003). Indeed, phenotypic flexibility is important in species expanding ranges or dispersing into new ones (Lande, 2009; Pigliucci et al., 2006; Price et al., 2003; Travis, 1994; West-Eberhard, 2005). Entry into a new environment via dispersal results in pressures favouring divergence from the ancestor. Moderate levels of phenotypic flexibility may therefore facilitate surviving in novel environments and later promote genetic changes linked to selection or local adaptation (Price et al., 2003).

The extent to which variation in appendage size results from genetic versus environmental sources is not well studied. Direct tests of adaptive flexibility in bill size have not been performed, although phenotypic flexibility could explain the temperature sensitivity of appendage growth in endotherms (Serrat, 2013; Serrat et al., 2008). The traditional explanation for temperature-dependent extremity growth is from a decreased or increased delivery of nutrients in the blood from thermoregulatory-induced vasoconstriction and vasodilation, respectively (Weaver \& Ingram, 1969). This 'vascularity hypothesis' predicts that bone growth and elongation is related to bone perfusion, with the latter dependent on ambient temperature. Serrat et al. (2008) addressed this hypothesis in mice, which exhibit extremity sizes that depend on environmental temperatures (Villarreal, Schlegel \& Prange, 2007). Mice were reared at cold $\left(7^{\circ} \mathrm{C}\right)$, intermediate-control $\left(21^{\circ} \mathrm{C}\right)$, and warm $\left(27^{\circ} \mathrm{C}\right)$ temperatures for approximately 9 weeks. Cold-reared mice had the lowest growth rates and reduced extremity blood flow, while the control and warm groups had similar growth and blood flow (Serrat et al., 2008). Appendage 
length was thus directly influenced by appendage temperature. They further tested the hypothesis that limb temperature directly modifies post-embryonic bone growth by examining growth plates in vitro. Warm-reared bones had a higher growth rate expressed as a percentage of starting size than cold-reared bones, and thus Serrat et al. (2008) argue that blood not only provides a source of nutrients and oxygen but also a source of heat, which is important for temperature-sensitive processes. Serrat et al. (2010) subsequently studied the direct effect of temperature on solute delivery to the bone's growth plate and found a minimal effect of rearing temperature on solute delivery, but that exercise can mitigate the cold-induced stunting of limb growth. Only loadbearing structures benefited from exercise-induced changes in nutrient delivery, whereas tails appeared to be sensitive directly to tissue temperature. Thus, it appears that that appendage length is primarily due to the effect of temperature rather than the rate of nutrient delivery to the growing bone.

\section{(3) Phenotypic flexibility in bill form and function}

Although the experiments by Serrat et al. $(2010,2008)$ were conducted on extremities in mice, extending similar arguments to the avian bill is plausible as they share similar underlying structures. Bills contain bones that are surrounded by highly vascularized tissue, which supply a constant flow of blood and nutrients (Van Hemert et al., 2012), similar to the highly vascularized tissue found in the tail of a mouse (Demicka \& Caputa, 1993a, $b$; Raman, Roberts \& Vanhuyse, 1983). The poorly insulated structure of a bill also experiences environmental conditions similar to those experienced by a poorly insulated foot of a mouse. These structural similarities suggest that bills may also experience a stunting effect of low temperature, with size constraints set by the underlying bony structures. There is precedent for flexibility in bill growth and morphology 
with respect to non-thermal effects (Bryant, 1978). In laboratory zebra finches (Taeniopygia guttata), Boag (1987) found that diet quality significantly impacts growth rates, showing that early-life growth effects can extend into adulthood, where body size, wing size and bill depth were all significantly different even though adult birds were no longer on restricted diets. That said, some species are capable of catch-up growth when removed from restricted diets (Negro, Chastin \& Bird, 1994). Non-pathological dietary restrictions led to changes in bill sizes of 3$10 \%$, which are similar to levels observed in studies where this degree of change was deemed to result from adaptive mechanisms acting on phenotypes (Boag, 1987). Combined, these results raise the question of whether all phenotypic variation in bill size is necessarily adaptive.

\section{(4) Critical period in development of bills}

To determine whether size or thermoregulatory function of the bill is a plastic response to environmental temperature, birds of similar genetic background need to be reared at different temperatures. NeSmith (1985) carried out such an experiment to determine whether temperature variation could be a direct cause of environmentally induced effects on the bill size of developing red-winged blackbirds (Agelaius phoeniceus). She randomly assigned four-day old birds from different populations to three environmental chambers: $(a)$ cold, $(b)$ hot and humid, and $(c)$ hot and dry. At 20 days of age, a significant number of birds in the cold chamber had proportionately shorter bills than did their siblings in the other chambers. This shows that the development of the bill is susceptible to rearing environment temperature, but since the effect was not seen in every population tested, there may be genetic variation within populations in their predisposition to environmental variation (James, 1991). In light of the results of Serrat $e t$ al. (2008), it is possible that birds from NeSmith (1985) reared in colder environments have 
proportionately smaller bills due to reduced blood flow and/or temperature during development. This may occur through a mechanism in which fledglings reared in colder environments reduce blood flow to extremities to conserve heat, although there is currently no evidence suggesting that this occurs in young birds. Indeed, work from juvenile toucans suggests that vasoconstriction of the bill in response to cold is minimal compared to what adults can do (Tattersall et al., 2009), however, in these species, the bill actively grows during the first year of life and may be constrained from exhibiting thermoregulatory responses; if there are changes in bill blood flow during a critical time in development, there may be permanent effects on bill growth. Differences in morphological characteristics among bird species arise and are consolidated within a relatively brief 1-2 day period within a 12-14 day period of development (Grant \& Grant, 2006). Because the bills are uninsulated and exposed, it is possible that birds reared in cold environments experience low enough temperatures that the flow of essential nutrients to the bill is reduced, thereby resulting in a reduction in size. Reduced blood flow at low temperatures during development may confer a fitness advantage in the ability to conserve heat through a smaller bill size as an adult, although whether these early developmental effects are fixed or reversible is unknown. Regardless of the relative role of genetic or environmental effects, it is no coincidence that the flexibility of appendage growth follows the same direction as that predicted from thermoregulatory hypotheses (i.e. Allen's Rule), and that different species experiencing different environmental constraints may show more or less evidence for phenotypic flexibility (Table 1).

Phenotypic flexibility of the bill in response to temperature has also been demonstrated in Japanese quail (Coturnix japonica) (Burness et al., 2013); birds raised in cold environments grew smaller bills than those raised in warm environments, consistent in direction with Allen's 
rule. This bill size difference persisted until birds were subsequently housed under common thermal conditions, where birds with smaller bills exhibited catch-up growth (Burness et al., 2013), similar to that observed in body mass of developing collared flycatchers (Ficedula albicollis) (Hegyi \& Torok, 2007). This phenotypic flexibility extended beyond morphology also to include the physiological control of thermoregulation through the bill. In the quail study, when mature birds were exposed acutely to $15^{\circ} \mathrm{C}$, birds that were raised in the cold were able to keep their bills cooler than birds raised in the warm conditions (Burness et al., 2013). Contrary to the morphological flexibility, where catch-up growth was demonstrated, these changes in physiological control persisted even after the mature birds were housed under the same thermal conditions. These results suggest that there is a permanent change in bill function and possibly the amount of vasculature or the degree of physiological control over the vasculature due to the thermal conditions experienced during development. Understanding these internal changes in the bill may help elucidate the mechanisms behind the evolution of the bill as a thermoregulatory organ, and may indicate the role which developmental plasticity and phenotypic flexibility (Piersma \& Drent, 2003) could play in the evolution of both the morphology and thermoregulatory functions of the bill. That early life events lead to persistent physiological differences, whereas morphological traits are reversibly plastic, is intriguing as it infers that 'matching' of thermoregulation function to local climatic conditions may be better achieved post-development by morphological, rather than physiological adaptations.

\section{(5) Evolutionary contributions versus phenotypic flexibility in bill morphology}

One way to investigate the contribution of genetic and non-genetic variation to sizerelated clines (James, 1970) is through transplant experiments in which individuals are 
exchanged among localities (James, 1991) and their morphologies assessed after being reared in these alternative environments. James \& NeSmith (1988) performed a reciprocal transplant experiment with redwing blackbird eggs between the warm climate of Florida and a cooler climate of Colorado. Florida blackbirds reared in Colorado were smaller than control birds and Colorado birds reared in Florida were larger than control birds. In contrast to body size, bill growth was retarded by transplantation to Colorado (warm source to cooler climate) and accelerated by transplantation to Florida (James \& NeSmith, 1988). Their results directly demonstrate that some proportion of bill shape is non-genetic. The increased bill growth in the warmer climate is plastic, which would allow the bird an increased thermoregulatory capacity, while the retarded growth in the cooler climate may be an attempt to conserve heat. It is also possible that the thermal environment affects earlier embryonic growth; for example, if the cooler environments limit bill mesenchymal proliferation, overall bill size would be smaller, which would result in smaller bill surface area, but subsequent heat conservation in the adult as an indirect consequence. The results from James \& NeSmith (1988) also support the intraspecific evidence for Allen's rule with the caveat that at least part of the bill growth is due to inherent differences in developmental phenotypic flexibility.

Common garden and reciprocal transplant experiments are primarily used as tools to uncover the adaptive significance of a trait, but they are also able to test the effect of a single environmental variable on an organism. Ballentine \& Greenberg (2010) compared bill size in swamp sparrows (Melospiza georgiana) taken from coastal (Delaware) and inland (Maryland) populations, and subsequently raised under common garden conditions. Although geographically close, the coastal habitats offer little shade, are water limited due to the high salinity of the ocean, and are windier than inland habitats (Greenberg et al., 2012b). Ballentine \& Greenberg 
(2010) found that birds derived from coastal populations had significantly larger bills than those from inland, and suggested that coastal populations have larger bills as an adaptation to new food sources. Coastal habitats have a lower abundance of seeds and a higher abundance of invertebrate prey, and having a larger bill may increase success in capturing and consuming prey (Ballentine \& Greenberg, 2010). These significant differences in bill size between the two populations raised under identical environments provided evidence for a genetic basis while also ruling out a plastic response to the environment.

\section{(6) Seasonal changes in bill size}

It has long been appreciated that avian bills change in size seasonally (Davis, 1954). The traditional explanation for seasonal effects on bill size has been a foraging-induced imbalance between growth and abrasion (see Section II.4). As feeding switches to harder substrates in the winter, wear outpaces growth and net growth is diminished, leading to shorter bills. These seasonal changes in bill size are known in a variety of species (Davis, 1954) where bill growth and/or wear do respond to changes in temporal variation in food abundance and food type (Gosler, 1987). Matthysen (1989) observed seasonal changes in bill size in nuthatches (Sitta europaea) that were ascribed to differences in abrasion rates; bills are smaller during the peak foraging season, peaking in size in the autumn. Matthysen (1989) makes the point that bill size in the nuthatches 'lags' behind what would be considered optimal for resource and trophic considerations, and refers to the abrasion hypothesis as 'non-adaptive' (i.e. a passive effect of dietary change rather than an optimisation). He also makes the point that changes in seasonal growth alone cannot explain the data since growth-based changes would be expected for both bill depth and length. Seasonal changes in oystercatcher bill size and shape have also been linked to 
differential growth and abrasion rates (Hulscher, 1985; White \& Gittin, 1964), although individual variation in bill length is extremely high (up to $\sim 10 \%$ of bill length) suggesting unaccounted contributions to bill size. In spite of the available information on seasonal flexibility in bill size, physiological explanations have only recently been considered as possible mechanisms (Greenberg et al., 2013). An extreme example of seasonal morphological change in bill structure not based on changes in abrasion rates occurs in the Atlantic puffin (Fratercula artica) (Harris, 2014) originally described by Bureau (1877). During the transition period from summer to winter the horny plates on the inner part of the beak are shed and the overall bill structure becomes much reduced in size and colour in the winter. In the spring, the regrowth on the upper and lower bill surfaces is described as flesh-like (Harris, 2014), with small feather-like projections appearing along the grooves of the growing plates, which would require a high degree of blood supply and vascularity. Whether this bill shedding affords an energetic saving during the winter has never been tested, although the seasonal size changes support a thermoregulatory explanation rather than a dietary-switch abrasion hypothesis.

To address seasonal contributions to bill size variation, Greenberg et al. (2012b) studied 1380 specimens from 10 species of saltmarsh sparrow along a latitudinal gradient finding that summer temperature explained $82-89 \%$ of the variance in bill size, whereas winter temperature was unrelated to bill size (Fig. 6). Greenberg et al. (2012b) attributed these results to different migratory behaviours of the birds; wintering in moderate climates may prevent strong selection from extremely cold temperatures (Greenberg et al., 2012b) or may possibly allow selection from other factors, such as foraging. However, the pattern may also result from the stronger selection effect of summer temperature in relation to thermoregulation through the bill. At elevated temperatures, if evaporative water loss cannot keep pace with heat generation, processes 
that enhance dry heat loss would be favoured; a larger bill would facilitate greater heat exchange. At this point, the 'thermoregulatory hypothesis' for variation in bill size is supported by a strong correlation between bill size and high summer temperature (Greenberg et al., 2012b), as opposed to selection against larger bills in cold climates to prevent heat loss Further research, however, is needed to establish whether individual fitness is influenced by heat loss through the bill.

Given the seasonal variability and species differences in bill size changes, it is clear that forces shaping bill size vary among species. With respect to Allen's rule, Danner \& Greenberg (2015) introduce a 'critical season hypothesis' to explain the variation in the degree to which Allen's rule is followed with respect to bill size. They proposed that the strength or applicability of Allen's rule depends on the 'season of critical thermal stress'. For example, smaller bill sizes may be advantageous in the cold to retain heat and larger bills beneficial to dissipate heat at higher temperatures, the season driving selection may differ. To address this question, Danner \& Greenberg (2015) examined song sparrows along the eastern coast of the USA, and found that winter temperatures were stronger predictors of bill size (smaller bills in colder habitats) than summer temperatures. Although still following the predictions from Allen's Rule, these results contrast with song sparrows on the west coast of the USA, where summer temperatures are strong predictors of bill size (larger bills in warmer habitats), and therefore the critical season is expected to vary geographically and possibly at even smaller scales.

\section{(7) Climate changes and bill size}

The observation that relative bill size is positively associated with climatic temperature both across and within species (Greenberg et al., 2012b; Symonds \& Tattersall, 2010) invites speculation that as the climate changes, then selection should likewise drive evolutionary change 
in bill size. More specifically, with the documented increases in global temperatures (Hartmann et al., 2013), we might observe shifts towards large relative bill size analogous to the changes in body size that have been attributed to the same mechanism (Gardner et al., 2011). Although few studies have specifically examined this issue, there is some evidence for increases in endotherm appendage size over the past century, in the manner predicted by Allen's rule (larger appendages as the climate has become warmer). Thus, tail lengths of Sorex cinereus shrews in Alaska have increased during the second half of the 20th century (Yom-Tov \& Yom-Tov, 2005). For birds, in a study of specimens of five Australian parrot species, Campbell-Tennant et al. (2015) found increases in bill size of $4-10 \%$ in four of the species in the period since 1871 (Fig. 7), and in three of those species there was also a correlation between maximum summer temperature at the localities in the year of collection and bill size. These results are certainly consistent with the idea that climatic warming is selecting for larger bills. However, at the moment it is not possible to rule out that the observed changes are due to factors other than temperature such as changes in habitat and food availability which have occurred over the same time period. Moreno-Rueda \& Rivas (2007) found similar increases in bill size over a 20-year period (1985-2005) in dippers (Cinclus cinclus) along rivers in south-eastern Spain, but they attributed these increases to changes in trophic niches induced by decreases in water flow. Ultimately, because any historical association between year and bill size is correlational, it is difficult to identify the proximate mechanism. However, if studies of a more diverse range of birds with different foraging strategies and across different habitats were to demonstrate similar increases in bill size this would provide more convincing evidence that a thermoregulatory adaptation was the cause of these increases. 


\section{HEAT TRANSFER AND BILL SIZE}

Peripheral structures that are involved in thermoregulation exchange heat with the environment in a manner dependent on two dominant traits: surface area and surface temperature. Additional factors, such as wind speed, humidity, solar radiation, surface reflectivity, and shape also contribute to heat exchange, but are beyond the scope of this review. Therefore, to understand the impact on heat exchange from structures such as the bill, total size as well as the degree of blood flow to the bill surface are the primary traits that may be responding to climate-related selection pressures. Actual measurements of heat transfer from bills are rare; the few studies that have examined this have done so using non-invasive thermal imaging to obtain surface temperatures of bills, limbs, and plumage, combined with fixed mount models of surface areas to estimate heat exchange (Greenberg et al., 2012a; Hagan \& Heath, 1980; Phillips \& Sanborn, 1994; Tattersall et al., 2009). To date, no studies have incorporated these measurements into the context of known biogeographical relationships as outlined herein, however, a simplified analysis of the potential importance of heat exchange is possible. Using published data on bill surface areas (Walsberg \& King, 1978) from birds ranging in body mass (3-650 g), and calculations from published heat transfer models (McCafferty et al., 2013; Tattersall, 2016a; Tattersall et al., 2009), we have estimated the minimum and maximum reasonable heat exchange (the sum of radiative and convective exchange) from the bill and normalise these to body mass scaling estimates of basal heat production ( $\mathrm{McNab}, 2002)$. We ran the models at a common ambient temperature $\left(T_{\mathrm{a}}=20^{\circ} \mathrm{C}\right)$, and set bill surface temperatures $\left(T_{\mathrm{s}}\right)$ 1,5 , and $10^{\circ} \mathrm{C}$ warmer than ambient temperature to mimic low, moderate, and high bill vasodilation ( $T_{\mathrm{s}}-T_{\mathrm{a}}$ is the driving force for heat exchange). Solar radiation was set to 0 in order to examine only heat loss to the environment. Forced convective heat transfer from the bill was 
modelled as a horizontal cylinder and all other parameters were held constant ( wind speed $=1$ $\mathrm{m} / \mathrm{s}$; relative humidity $=0.5$ ). Calculations follow the principles outlined by Gates (2003) with further elaboration provided in the 'Thermimage' package for R (Tattersall, 2016b). The results of this heat transfer modelling are shown in Fig. 8.

The first trend of note is that at larger body mass, the effectiveness of the bill as a heat loss organ, expressed as the proportion of basal heat production, is diminished (Fig. 8). The negative relationship with body mass is reflective of geometric constraints, since surface area does not scale isometrically with mass, and the birds used for this model all exhibit small bill surface areas ( $\sim 2 \%$ of total body surface area). Interestingly, however, the range of heat exchange is high (from $\sim 1.5$ up to $40 \%$ of BMR), especially at small body sizes. The reason for this is that convective heat loss from small surfaces is much higher per unit surface area than from larger surfaces, due to how convection depends on Reynolds number (Gates, 2003). Furthermore, relatively small changes in $T_{\mathrm{s}}-T_{\mathrm{a}}\left(1,5,10^{\circ} \mathrm{C}\right.$ are based on previous research; Greenberg et al., 2012a; Tattersall et al., 2009) dramatically alter the potential importance of the bill as a heat exchanger. Similar trends would be expected for any other uninsulated surface, such as the limbs, although incorporating the efficiencies inherent to counter-current vascular systems complicates the situation.

Overall, then, if the bill is performing a critical role in thermoregulation, this analysis provides a few predictions. Larger relative surface areas are more likely to evolve in larger birds, at least in warm climates, since the actual effectiveness of heat exchange decreases with increasing body size. Likewise, small-bodied birds in cold climates would be under stronger selection pressures to reduce heat loss from the bill. Conversely, the disproportionate influence of altering blood flow to the bill surface in small birds suggests that variation in the use of bill as 
a thermal radiator should be greatest in small birds, due to the much greater scope for heat transfer. Therefore, unlike early impressions about the low potential for heat exchange from avian bills (Scholander, 1955, 1956), we present mathematical support for levels of heat exchange that are quite substantial, and recommend that thermoregulatory concerns should be considered in any studies of bill (or limb) morphological responses, especially in species that span wide latitudinal or climatic gradients.

\section{CONCLUSIONS}

(1) Although the bill has been primarily shaped by evolutionary pressures related to feeding, the keratinous, featherless structure of the beak has enabled selection for a novel means of thermoregulation.

(2) Bills are thermoregulatory structures, and the notion that thermoregulation is restricted only to large-billed species is erroneous.

(3) Thermal considerations have shaped the evolution of the avian bill. The thermal capabilities of bills coupled with the morphological manifestations of Allen's rule provide a comprehensive explanation of the proximate causes behind temperature effects on bill size in birds.

(4) Common garden and transplant experiments have shown that populations may have adapted to different temperature conditions or may possibly retain growth flexibility should conditions change. In this manner, bills behave as other appendages in endotherms, which are plastic with respect to rearing temperatures.

(5) Bills are well vascularized structures with dynamic changes in blood flow. Future analysis of bill vascular morphology in widespread taxonomic groups may also help us understand the environmental factors which influenced the evolution of thermoregulatory exaptation in the bill. 
(6) Seasonal variation in bill size is common. The proximate mechanism in some cases is related to dietary-induced abrasion and in other cases to temperature-induced enhancement of ramphotheca growth.

(7) Bill size is often strongly related to local climate conditions, and population-level changes in bill size reflect evolutionary changes geared towards climate. Bill size, along with body size, could serve as a metric to examine the impact of climate on avian populations, and provide valuable insights into the evolutionary dynamics of functional morphology.

(8) Heat transfer models demonstrate that surface area and surface temperature both contribute to the potential role of the bill as a heat exchanger. Understanding of the role of bills as thermal radiators under selection by local climate would be greatly improved with actual bill surface areas as well as surface temperatures obtained from birds in natural settings. 


\section{ACKNOWLEDGEMENTS}

We would like to dedicate this review to Dr Russ Greenberg, whose ideas and unbridled enthusiasm for bringing diverse fields together helped to forge the ideas presented in this review. We would also like to thank Matteson DeLuca and Kristen Schuppe for assisting with the early development of ideas presented herein, and Rebecca Readhead for helping to compile the list of studies in Table 1. The research program of G.J.T. is supported by the Natural Sciences and Engineering Research Council of Canada. 


\section{REFERENCES}

Aввотт, I. A. N. (1974). Morphological changes in isolated populations of some passerine bird species in Australia. Biological Journal of the Linnean Society 6, 153-168.

Abzhanov, A., Protas, M., Grant, B. R., Grant, P. R. \& Tabin, C. J. (2004). Bmp4 and morphological variation of beaks in Darwin's finches. Science 305, 1462-1465.

ADKISSON, C. S. (1981). Geographic variation in vocalizations and evolution of North American pine grosbeaks. The Condor 83, 277.

Al-Hilli, F. \& Wright, E. A. (1983). The effects of changes in the environmental temperature on the growth of tail bones in the mouse. British Journal of Experimental Pathology 64, 34-42.

AlDRICH, J. W. \& JAMES, F. C. (1991). Ecogeographic variation in the American robin (Turdus migratorius). The Auk 108, 230-249.

Allen, J. A. (1877). The influence of physical conditions in the genesis of species. Radical Review 1, 108-140.

Amiot, C., Lorvelec, O., Mandon-Dalger, I., Sardella, A., Lequilliec, P. \& Clergeau, P. (2007). Rapid morphological divergence of introduced red-whiskered Bulbuls Pycnonotus jocosus in contrasting environments. Ibis 149, 482-489.

Angilletta, M. J., Jr., Cooper, B. S., Schuler, M. S. \& Boyles, J. G. (2010). The evolution of thermal physiology in endotherms. Front Biosci (Elite Ed) 2, 861-81.

Arad, Z., Midtgard, U. \& Bernstein, M. H. (1989). Thermoregulation in turkey vultures vascular anatomy, arteriovenous heat-exchange, and behavior. Condor 91, 505-514.

BADYAeV, A. V., Young, R. L., OH, K. P.\& AdDison, C. (2008). Evolution on a local scale: developmental, functional, and genetic bases of divergence in bill form and associated changes in song structure between adjacent habitats. Evolution 62, 1951-64.

BAllentine, B. \& GReEnBERG, R. (2010). Common garden experiment feveals genetic control of phenotypic divergence between swamp sparrow subspecies that lack divergence in neutral genotypes. PLoS One 5, 4.

Baudinette, R. V., Loveridge, J. P., Wilson, K. J., Mills, C. D. \& Schmidt-Nielsen, K. (1976). Heat loss from feet of Herring Gulls at rest and during flight. American Journal of Physiology 230, 920-924.

Bears, H., C. Drever, M. \& Martin, K. (2008). Comparative morphology of dark-eyed juncos Junco hyemalis breeding at two elevations: a common aviary experiment. Journal of Avian Biology 39, 152-162.

BEHLE, W. H. (1973). Clinal variation in white-throated swifts from Utah and the rocky mountain region. The Auk 90, 229-306.

BENÍTEZ-DÍEZ, H. (1993). Geographic variation in coloration and morphology of the acorn woodpecker. The Condor 95, 63-71.

BENKMAN, C. W. (1987). Crossbill foraging behavior, bill structure, and patterns of food profitability. The Wilson Bulletin 99, 351-368.

BenKman, C. W. (1993). Adaptation to single resources and the evolution of crossbill (Loxia) diversity. Ecological Monographs 63, 305-325.

BoAg, P. T. (1987). Effects of nestling diet on growth and adult size of zebra finches (Poephila guttata). Auk 104, 155-166.

BOAG, P. T. \& GRANT, P. R. (1981). Intense natural selection in a population of Darwin's finches. (Geospizinae) in the Galapagos. Science 214, 82-85. 
Bonser, R. H. C. (1996). Comparative mechanics of bill, claw, and feather keratin in the common starling Sturnus vulgaris. Journal of Avian Biology 27, 175-177.

Borras, A., PAscual, J. \& SEnAR, J. C. (2000). What do different bill measures measure and what is the best method to use in granivorous birds? Journal of Field Ornithology 71, 606-611.

BOWERS, D. E. (1960). Correlation of variation in the wrentit with environmental gradients. The Condor 62, 91-120.

Bowman, R. I. (1961). Morphological differentiation and adaptation in the Galápagos finches. University of California Publications in Zoology.

Brittan-Powell, E. F., Dooling, R. J., Larsen, O. N. \& Heaton, J. T. (1997). Mechanisms of vocal production in budgerigars (Melopsittacus undulatus). Journal of the Acoustical Society of America 101, 578-589.

BRYANT, D. M. (1978). Environmental influences on growth and survival of nestling House Martins, Delichon urbica. Ibis 120, 272-283.

Bureau, L. (1877). De la mue du bec et des ornements palpebraux. Bulletin Societé Zoologie France 2, 377-399.

Burness, G., Huard, J. R., Malcolm, E. \& Tattersall, G. J. (2013). Post-hatch heat warms adult beaks: irreversible physiological plasticity in Japanese quail. Proceedings of the Royal Society B-Biological Sciences $\mathbf{2 8 0}$.

Cain, J. W., Krausman, P. R., Rosenstock, S. S. \& Turner, J. C. (2006). Mechanisms of thermoregulation and water balance in desert ungulates. Wildlife Society Bulletin 34, 570581.

Campbell-Tennant, D. J. E., Gardner, J. L., Kearney, M. R. \& Symonds, M. R. E. (2015). Climate-related spatial and temporal variation in bill morphology over the past century in Australian parrots. Journal of Biogeography 42, 1163-1175.

Cardilini, A. P., Buchanan, K. L., Sherman, C. D. L., Cassey, P. \& Symonds, M. R. E. (2016). Tests of ecogeographical relationships in a non-native species: what rules avian morphology? Oecologia 181, 783-793.

Caro, L. M., Caycedo-Rosales, P. C., Bowie, R. C. K., Slabbekoorn, H. \& Cadena, C. D. (2013). Ecological speciation along an elevational gradient in a tropical passerine bird? Journal of Evolutionary Biology 26, 357-374.

CARTAR, R. V. \& Morrison, R. I. G. (2005). Metabolic correlates of leg length in breeding arctic shorebirds: the cost of getting high. Journal of Biogeography 32, 377-382.

ConAnt, S. (1988). Geographic variation in the Laysan finch (Telespyza cantans). Evolutionary Ecology 2, 270-282.

Conklin, J. R., Battley, P. F., Potter, M. A. \& Ruthrauff, D. R. (2011). Geographic variation in morphology of Alaska-breeding bar-tailed godwits (Limosa lapponica) is not maintained on their nonbreeding grounds in New Zealand. The Auk 128, 363-373.

Cuthill, I., Witter, M. \& Clarke, L. (1992). The function of bill-wiping. Animal Behaviour 43, 103-115.

DAnner, R. M. \& Greenberg, R. (2015). A critical season approach to Allen's rule: bill size declines with winter temperature in a cold temperate environment. Journal of Biogeography 42, 114-120.

DARWIN, C. (1871). The descent of man: and selection in relation to sex. J. Murray, London.

DAVIS, J. (1954). Seasonal changes in bill length of certain passerine birds. The Condor 56, 142149. 
DeBAT, V. \& DAVID, P. (2001). Mapping phenotypes: canalization, plasticity and developmental stability. Trends in Ecology \& Evolution 16, 555-560.

DemickA, A. \& CAPUTA, M. (1993a). Different effects of warm rearing and heat acclimation on the development of cutaneous arteriovenous anastomoses in rats. Journal of Thermal Biology 18, 257-262.

DEMICKA, A. \& CAPUTA, M. (1993b). Effect of warm rearing on the development of thermolytic effectors in rats. Journal of Thermal Biology 18, 251-256.

Dénes, F. V., Silveira, L. F., Seipke, S., Thorstrom, R., Clark, W. S. \& Thiollay, J.-M. (2011). The white-collared kite (Leptodon forbesi Swann, 1922) and a review of the Taxonomy of the grey-headed kite (Leptodon cayanensis Latham, 1790). The Wilson Journal of Ornithology 123, 323-331.

DiAmOND, A. W. (1973). Altitudinal variation in a resident and a migrant passerine on Jamaica. The Auk 90, 610-618.

Ederstrom, H. E. \& Brumleve, S. J. (1964). Temperature gradients in the legs of coldacclimatized pheasants. American Journal of Physiology 207, 457-459.

ENCYClOPAEDIA BRITTANICA (2014). In Encyclopaedia Britannica Online. Encyclopædia Britannica Inc., Online.

FLETCHER, N. H. (1988). Bird song - a quantitative acoustic model. Journal of Theoretical Biology 135, 455-481.

Fooden, J. \& AlBrecht, G. H. (1999). Tail-length evolution in Fascicularis-group macaques (Cercopithecidae : Macaca). International Journal of Primatology 20, 431-440.

FORDYCE, J. A. (2006). The evolutionary consequences of ecological interactions mediated through phenotypic plasticity. Journal of Experimental Biology 209, 2377-2383.

Francis-WeSt, P., LADHER, R., BARLOW, A. \& GRAVESON, A. (1998). Signalling interactions during facial development. Mechanisms of Development 75, 3-28.

Fritz, J. A., Brancale, J., Tokita, M., Burns, K. J., Hawkins, M. B., Abzhanov, A. \& BRENNER, M. P. (2014). Shared developmental programme strongly constrains beak shape diversity in songbirds. Nature Communications 5.

Gardner, J. L., Peters, A., Kearney, M. R., Joseph, L. \& Heinsohn, R. (2011). Declining body size: a third universal response to warming? Trends in Ecology \& Evolution 26, 285-291.

Garnett, M. C. (1981). Body size, its heritability and influence on juvenile survival among great tits, Parus major. Ibis 123, 31-41.

Gates, D. M. (2003). Biophysical Ecology. In Dover Books on Biology Ser, pp. 656. Dover Publications, Incorporated, Mineola.

GEHLBACH, F. R. (2003). Body size variation and evolutionary ecology of eastern and western screech owls. The Southwestern Naturalist 48, 70-80.

Gibson, D. D. \& Kessel, B. (1989). Geographic variation in the marbled godwit and description of an Alaska subspecies. The Condor 91, 436.

Gilbert, S. F. (2010). Developmental biology, 9th edition. Sinauer Associates, Sunderland, MA.

Giraudeau, M., Nolan, P. M., Black, C. E., Earl, S. R., Hasegawa, M. \& McGraw, K. J. (2014). Song characteristics track bill morphology along a gradient of urbanization in house finches (Haemorhous mexicanus). Frontiers in Zoology 11.

Giuliano, M., Griggio, M. \& Pilastro, A. (2002). The geographical distribution of populations of the large-billed subspecies of reed bunting matches that of its main winter food. Biological Journal of the Linnaean Society 75, 21-26. 
Gosler, A. G. (1987). Pattern and process in the bill morphology of the great tit Parus major. Ibis 129, 451-476.

Gould, S. J. \& VRBA, E. S. (1982). Exaptation - a missing term in the science of form. Paleobiology 7, 4-15.

GRANT, B. R. \& GRANT, P. R. (1993). Evolution of Darwin finches caused by a rare climatic event. Proceedings of the Royal Society B-Biological Sciences 251, 111-117.

Grant, P. R. (1965). The adaptive significance of some size trends in island birds. Evolution 19, 355-367.

Grant, P. R. (1979a). Ecological and morphological variation of Canary Island blue tits, Parus caeruleus (Aves: Paridae). Biological Journal of the Linnean Society 11, 103-129.

Grant, P. R. (1979b). Evolution of the chaffinch, Fringilla coelebs, on the Atlantic islands. Biological Journal of the Linnean Society 11, 301-332.

Grant, P. R. \& GRANT, B. R. (1995). Predicting microevolutionary responses to directional selection on heritable variation. Evolution 49, 241-251.

Grant, P. R. \& GRANT, B. R. (2000). Non-random fitness variation in two populations of Darwin's finches. Proceedings of the Royal Society B-Biological Sciences 267, 131-138.

Grant, P. R. \& GRANT, B. R. (2002a). Adaptive radiation of Darwin's finches. American Scientist 90, 130-139.

GRANT, P. R. \& GRANT, B. R. (2002b). Unpredictable evolution in a 30-Year study of Darwin's finches. Science 296, 296.

Grant, P. R. \& Grant, B. R. (2005). Darwin's Finches. Current Biology 15, 614-615.

GRANT, P. R. \& GRANT, B. R. (2006). Evolution of character displacement in Darwin's finches. Science 313.

Gratto-Trevor, C., Morrison, R. I. G., Mizrahi, D., Lank, D. B., Hicklin, P. \& SpaAns, A. L. (2012). Migratory connectivity of semipalmated sandpipers: winter distribution and migration routes of breeding populations. Waterbirds 35, 83-95.

GRAVES, G. R. (1991). Bergmann's rule near the equator: latitudinal clines in body size of an Andean passerine bird. Proceedings of the National Academy of Sciences 88, 2322-2325.

GreEN, P. (1981). Some results from trapping rooks. Ringing and Migration 3, 203-212.

GREENBERG, R. \& DANNER, R. M. (2012). The influence of the California marine layer on bill size in a generalist songbird. Evolution 66, 3825-3835.

Greenberg, R. \& DANner, R. M. (2013). Climate, ecological release and bill dimorphism in an island songbird. Biology Letters 9.

GREENBERG, R. \& OlSEN, B. J. (2010). Bill size and dimorphism in tidal-marsh sparrows: islandlike processes in a continental habitat. Ecology 91, 2428-2436.

Greenberg, R., Cadena, V., Danner, R. M. \& TAtTersall, G. J. (2012a). Heat loss may explain bill size differences between birds occupying different habitats. Plos One 7.

Greenberg, R., Danner, R., Olsen, B. \& Luther, D. (2012). High summer temperature explains bill size variation in salt marsh sparrows. Ecography 35, 146-152.

Greenberg, R., Etterson, M. \& DAnner, R. M. (2013). Seasonal dimorphism in the horny bills of sparrows. Ecology and Evolution 3, 389-398.

Gutiérrez-Pinto, N., McCracken, K. G., Alza, L., Tubaro, P., Kopuchian, C., Astie, A. \& CADENA, C. D. (2014). The validity of ecogeographical rules is context-dependent: testing for Bergmann's and Allen's rules by latitude and elevation in a widespread Andean duck. Biological Journal of the Linnean Society 111, 850-862. 
HAFEZ, E. S. E. (1964). Behavioural thermoregulation in mammals and birds. International Journal of Biometerology 7, 231-240.

Hagan, A. A. \& HeAth, J. E. (1980). Regulation of heat loss in the duck by vasomotion in the bill. Journal of Thermal Biology 5, 95-101.

Hamilton, T. H. (1958). Adaptive variation in the genus Vireo. Wilson Bulletin 70, 307-346.

HANDFORD, P. (1983). Continental patterns of morphological variation in a South American Sparrow. Evolution 37, 920.

HARris, M. (2014). Aging Atlantic puffins Fratercula artica in summer and winter. Seabird 27, $22-40$.

Hartmann, D. L., Klein Tank, A. M. G., Rusticucci, M., Alexander, L. V., Brönnimann, S., Charabi, Y. A.-R., Dentener, F. J., Dlugokencky, E. J., Easterling, D. R., Kaplan, A., Soden, B. J., ThORne, P. W., WILD, M. \& ZhAi, P. M. (2013). Observations: atmosphere and surface. Climate change 2013: the physical science basis. Contribution of Working Group I to the fifth assessment report of the Intergovernmental Panel on Climate Change (ed. T. F. Stocker, D. Qin, G.-K. Plattner, M. Tignor, S. K. Allen, J. Boschung, A. Nauels, Y. Xia, V. Bex and P. M. Midgely), pp. 159-254. Cambridge University Press, Cambridge, UK.

Hausberger, M., Black, J. M. \& Richard, J. P. (1991). Bill opening and sound spectrum in barnacle goose loud calls - individuals with wide mouths have higher pitched voices. Animal Behaviour 42, 319-322.

HAYES, F. E. (2003). Geographic variation in the great pampa-finch Embernagra platensis complex: evidence for two species. Ardeola 50, 223-235.

HegYi, G. \& TOROK, J. (2007). Developmental plasticity in a passerine bird: an experiment with collared flycatchers Ficedula albicollis. Journal of Avian Biology 38, 327-334.

Helms, J. A. \& Schneider, R. A. (2003). Cranial skeletal biology. Nature 423, 326-31.

Herrel, A., Podos, J., Huber, S. K. \& Hendry, A. P. (2005). Bite performance and morphology in a population of Darwin's finches: implications for the evolution of beak shape. Functional Ecology 19, 43-48.

Herrel, A., Podos, J., Vanhooydonck, B. \& Hendry, A. P. (2009). Force-velocity trade-off in Darwin's finch jaw function: a biomechanical basis for ecological speciation? Functional Ecology 23, 119-125.

Herrel, A., Soons, J., Aerts, P., Dirckx, J., Boone, M., Jacobs, P., Adriaens, D. \& Podos, J. (2010). Adaptation and function of the bills of Darwin's finches: divergence by feeding type and sex. Emu 110, 39-47.

HILL, G. E. (1993). Geographic variation in the carotenoid plumage pigmentation of male house finches (Carpodacus mexicanus). Biological Journal of the Linnean Society 49, 63-86.

Hsu, Y.-C., Shaner, P.-J., Chang, C.-I., Ke, L. \& KaO, S.-J. (2013). Trophic niche width increases with bill-size variation in a generalist passerine: a test of niche variation hypothesis. Journal of Animal Ecology 83, 450-459.

Hughes, A. F. W. (1934). On the development of the blood vessels in the head of the chick. Philosophical Transactions of the Royal Society of London. Series B, Biological Sciences 224, 75-130.

HulscheR, J. B. (1985). Growth and abrasion of the oystercatcher bill in relation to dietary switches. Netherlands Journal of Zoology 35, 124-154.

JAMES, F. C. (1970). Geographic size variation in birds and its relationship to climate. Ecology 51, 365-390. 
JAMES, F. C. (1991). Complementary descriptive and experimental studies of clinal variation in birds. American Zoologist 31, 694-706.

JAMES, F. C. \& NeSMith, C. (1988). Non-genetic effects in geographic differences among nestling populations of Red-winged Blackbirds. In Acta XIX Congressus Internationalis Orthinologici, vol. 2 (ed. H. Ouellet), pp. 1424-1433.

JOHANSEN, K. \& BECH, C. (1983). Heat conservation during cold exposure in birds (vasomotor and respiratory implications. Polar Research 1, 259-268.

Johansen, K. \& Millard, R. W. (1973). Vascular responses to temperature in foot of Giant Fulmar, Macronectes giganteus. Journal of Comparative Physiology 85, 47-64.

Johansson, C., Linder, E., HARdin, P. \& White, C. (1998). Bill and body size in the peregrine falcon, north versus south: is size adaptive? Journal of Biogeography 25, 265-273.

Johnston, R. F. (1969). Character variation and adaptation in European sparrows. Systematic Zoology 18, 206.

Johnston, R. F. (1992). Geographic size variation in rock pigeons, Columba livia. Bolletino di zoologia 59, 111-116.

Johnston, R. F. \& SELANDER, R. K. (1973). Evolution in the house sparrow. III. Variation in size and sexual dimorphism in Europe and North and South America. The American Naturalist 107, 373.

Keller, L. F., Grant, P. R., Grant, B. R. \& Petren, K. (2001). Heritability of morphological traits in Darwin's Finches: misidentified paternity and maternal effects. Heredity 87, 325336.

Kinnard, T. B. \& Westneat, D. F. (2009). Phenotypic and genetic variance of House Sparrows (Passer domesticus) early in development. Auk 126, 884-895.

Kirschel, A. N. G., Blumstein, D. T. \& Smith, T. B. (2009). Character displacement of song and morphology in African tinkerbirds. Proceedings of the National Academy of Sciences 106, 8256-8261.

KUENZEL, W. J. (2007). Neurobiological basis of sensory perception: Welfare implications of beak trimming. Poultry Science 86, 1273-1282.

KunZ, C. \& EKMAN, J. (2000). Genetic and environmental components of growth in nestling blue tits (Parus caeruleus). Journal of Evolutionary Biology 13, 199-212.

LACK, D. L. (1947). Darwin's finches. Univ. Press, Cambridge Eng.

LAIOLO, P. \& ROLANDO, A. (2001). Ecogeographic correlates of morphometric variation in the red-billed chough Pyrrhocorax pyrrhocorax and the alpine chough Pyrrhocorax graculus. Ibis 143, 602-616.

LANDE, R. (2009). Adaptation to an extraordinary environment by evolution of phenotypic plasticity and genetic assimilation. Journal of Evolutionary Biology 22, 1435-1446.

LARousse, P. \& AugÉ, P. (1928). Larousse du XXe siècle. Librairie Larousse, Paris.

LEAFloOr, J. O., ANKNEY, C. D. \& RusCH, D. H. (1998). Environmental effects on body size of Canada geese. The Auk 115, 26-33.

LeE, S. H., Fu, K. K., Hui, J. N. \& Richman, J. M. (2001). Noggin and retinoic acid transform the identity of avian facial prominences. Nature 414, 909-912.

LOUCHART, A. \& Viriot, L. (2011). From snout to beak: the loss of teeth in birds. Trends in Ecology \& Evolution 26, 663-673.

LuCAs, A. M. \& StetTenheIM, P. R. (1972). Avian anatomy: integument. U.S. Agricultural Research Service, Washington. 
Luther, D. \& GREENBERG, R. (2014). Habitat type and ambient temperature contribute to bill morphology. Ecology and Evolution 4, 699-705.

MAJOR, R. E. (2012). Latitudinal and insular variation in morphology of a small Australian passerine: consequences for dispersal distance and conservation. Australian Journal of Zoology 60, 210.

Mallarino, R., Grant, P. R., Grant, B. R., Herrel, A., Kuo, W. P. \& Abzhanov, A. (2011). Two developmental modules establish 3D beak-shape variation in Darwin's finches. Proceedings of the National Academy of Sciences of the United States of America 108, 4057-4062.

Maloney, S. K. \& DAwson, T. J. (1994). Thermoregulation in a large bird, the Emu (Dromaius novaehollandiae). Journal of Comparative Physiology B-Biochemical Systemic and Environmental Physiology 164, 464-472.

Martin, J. L. (1991). Patterns and significance of geographical variation in the Blue Tit (Parus caeruleus). Auk 108, 820-832.

MARTineAu, L. \& LAROCHELlE, J. (1988). The cooling power of pigeon legs. Journal of Experimental Biology 136, 193-208.

Mascitti, V. \& Kravetz, F. O. (2002). Bill morphology of South American flamingos. Condor 104, 73-83.

Matthysen, E. (1989). Seasonal variation in bill morphology of nuthatches Sitta europaea: Dietary adaptations or consequences. Ardea 77, 117-125.

MAYR, E. (1956). Geographical character gradients and climatic adaptation. Evolution 10, 105108.

MAYR, E. (1970). Populations, species and evolution. . Harvard University Press, Cambridge, MA.

MAYR, E. (1988). Toward a new philosophy of biology : observations of an evolutionist. Belknap Press of Harvard University Press, Cambridge, Mass.

McCafferty, D. J., Gilbert, C., Thierry, A. M., Currie, J., Le Maho, Y. \& Ancel, A. (2013). Emperor penguin body surfaces cool below air temperature. Biology Letters 9.

McNab, B. K. (2002). The Physiological Ecology of Vertebrates: A View from Energetics. Cornell University Press.

MENGEL, R. M. \& JACKSON, J. A. (1977). Geographic variation of the red-cockaded woodpecker. The Condor 79, 349.

MERILÄ, J. (1997). Quantitative trait and allozyme divergence in the Greenfinch (Carduelis chloris, Aves: Fringillidae). Biological Journal of the Linnean Society 61, 243-266.

MidTGÅRD, U. (1980). Arteriovenous anastomoses and vascularity in the feet of eiders and gulls (Aves). Zoomorphology 96, 263-270.

MidTGÅRD, U. (1981). The rete tibiotarsale and arterio-venous association in the hind limb of birds: a comparative morphological study on counter-current heat exchange systems. Acta Zoologica 62, 67-87.

MidTGÅRD, U. (1984a). Blood vessels and the occurrence of arteriovenous anastomoses in cephalic heat loss areas of mallards, Anas platyrhynchos (Aves). Zoomorphology 104, 323-335.

MidTGÅRD, U. (1984b). The blood vascular system in the head of the herring gull (Larus argentatus). Journal of Morphology 179, 135-152.

Millard, R. W. \& Reite, O. B. (1970). Peripheral vascular response to norepinephrine at temperatures from 2 to 40 degrees C. Journal of Applied Physiology 38, 26-30. 
MinouX, M. \& RiJLI, F. M. (2010). Molecular mechanisms of cranial neural crest cell migration and patterning in craniofacial development. Development 137, 2605-21.

Moreno-RuedA, G. \& Rivas, J. M. (2007). Recent changes in allometric relationships among morphological traits in the dipper (Cinclus cinclus). Journal of Ornithology 148, 489494.

MORRISON, M. L. (1983). Analysis of geographic variation in the Townsend's warbler. The Condor 85, 385.

Mosimann, J. E. \& JAMES, F. C. (1979). New statistical methods for allometry with application to Florida red-winged blackbirds. Evolution 33, 444.

NeBEL, S. (2005). Latitudinal clines in bill length and sex ratio in a migratory shorebird: a case of resource partitioning? Acta Oecologica 28, 33-38.

Nebel, S., Rogers, K. G., Minton, C. D. T. \& Rogers, D. I. (2013). Is geographical variation in the size of Australian shorebirds consistent with hypotheses on differential migration? Ети 113, 99.

Negro, J. J., Chastin, A. \& Bird, D. M. (1994). Effects of short-term food-deprivation on growth of hand-reared American Kestrels. Condor 96, 749-760.

NeSmith, C. C. (1985). The effect of the physical environment on the development of redwinged blackbird nestlings, MSc Thesis, Florida State University, 85 pp.

NiLES, D. M. (1973). Adaptive variation in body size and skeletal proportions of horned larks of the Southwestern United States. Evolution 27, 405.

Noiva, R. M., Menezes, A. C. \& Peleteiro, M. C. (2014). Influence of temperature and humidity manipulation on chicken embryonic development. BMC Veterinary Research 10.

NudDS, R. L. \& Oswald, S. A. (2007). An interspecific test of Allen's rule: Evolutionary implications for endothermic species. Evolution 61, 2839-2848.

Olson, S. L. \& FedUCCIA, A. (1980). Relationships and Evolution of Flamingos (Aves: Phoenicopteridae). In Smithsonian Contributions to Zoology, pp. 73 pages. Smithsonian Institute.

Olson, V. A., Davies, R. G., Orme, C. D. L., Thomas, G. H., Meiri, S., Blackburn, T. M., Gaston, K. J., Owens, I. P. F. \& Bennett, P. M. (2009). Global biogeography and ecology of body size in birds. Ecology Letters 12, 249-259.

OXFORD ENGLISH DictionARY (2015). "bill, v.2". Oxford University Press.

PARTRIDGE, L. \& Pring-Mill, F. (1977). Canary Island blue tits and English coal Ttts: Convergent evolution? Evolution 31, 657.

Phillips, P. K. \& SANBORN, A. F. (1994). An infrared, thermographic study of surfacetemperature in 3 ratites - ostrich, emu and double wattled cassowary. Journal of Thermal Biology 19, 423-430.

Picard, K., Thomas, D. W., Festa-Bianchet, M. \& Lanthier, C. (1994). Bovid horns: an important site for heat loss during winter? Journal of Mammalogy 75, 710-713.

Piersma, T. \& Drent, J. (2003). Phenotypic flexibility and the evolution of organismal design. Trends in Ecology \& Evolution 18, 228-233.

Pigliucci, M., Murren, C. J. \& Schlichting, C. D. (2006). Phenotypic plasticity and evolution by genetic assimilation. Journal of Experimental Biology 209, 2362-2367.

Podos, J. \& Nowicki, S. (2004). Beaks, adaptation, and vocal evolution in Darwin's finches. Bioscience 54, 501-510. 
Podos, J., Southall, J. A. \& Rossi-Santos, M. R. (2004). Vocal mechanics in Darwin's finches: correlation of beak gape and song frequency. Journal of Experimental Biology 207, 607-619.

Porter, R. G. \& WitMer, L. M. (2016). Avian cephalic vascular anatomy, sites of thermal exchange, and the rete ophthalmicum. The Anatomical Record (in press).

POWER, D. M. (1970). Geographic variation in the surface/volume ratio of the bill of red-winged blackbirds in relation to certain geographic and climatic factors. The Condor 72, 299-304.

Power, D. M. \& AINLEY, D. G. (1986). Seabird geographic variation: similarity among populations of leach's storm-petrel. The Auk 103, 575-585.

Price, T. D., Grant, P. R., GiBBS, H. L. \& BoAG, P. T. (1984). Recurrent patterns of natural selection in a population of Darwin's finches. Nature 309, 787-789.

Price, T. D., QVARnstrom, A. \& IRWIn, D. E. (2003). The role of phenotypic plasticity in driving genetic evolution. Proceedings of the Royal Society B-Biological Sciences 270, 1433-1440.

RAMAn, E. R., Roberts, M. F. \& VANhuYse, V. J. (1983). Body temperature control of rat tail blood flow. American Journal of Physiology 245, R426-R432.

REEBS, S. G. (1986). Sleeping behavior of black-billed magpies under a wide-range of temperatures. Condor 88, 524-526.

REMSEN, J. V. J. (1991). Community ecology of neotropical kingfishers. University of California Publications in Zoology, Berkeley.

RISING, J. D. (1987). Geographic variation of sexual dimorphism in size of savannah sparrows (Passerculus sandwichensis): A test of hypotheses. Evolution 41, 514.

RISING, J. D. (1988). Geographic variation in sex ratios and body size in wintering flock of savannah sparrows (Passerculus sandwichnesis). Wilson Bulletin 100, 183-203.

SAKAI, H. F., RALPH, C. J. \& JENKINS, C. D. (1989). Foraging ecology of the Hawaiian crow, an endangered generalist. Condor 88, 211-219.

Santagati, F. \& RiJLi, F. M. (2003). Cranial neural crest and the building of the vertebrate head. Nature Reviews Neuroscience 4, 806-818.

Sato, A., Tichy, H., O'hUigin, C., Grant, P. R., Grant, B. R. \& Klein, J. (2001). On the origin of Darwin's finches. Molecular Biology and Evolution 18, 299-311.

SCHEINER, S. M. (1993). Genetics and evolution of phenotypic plasticity. Annual Review of Ecology and Systematics 24, 35-68.

Schluter, D., Price, T. D. \& Grant, P. R. (1985). Ecological character displacement in Darwin finches. Science 227, 1056-1059.

SCHOLANDER, P. F. (1955). Evolution of climatic adaptation in homeotherms. Evolution 9, 15-26.

SCHOLANDER, P. F. (1956). Climatic rules. Evolution 10, 339-340.

Scott, G. R., Cadena, V., Tattersall, G. J. \& Milsom, W. K. (2008). Body temperature depression and peripheral heat loss accompany the metabolic and ventilatory responses to hypoxia in low and high altitude birds. Journal of Experimental Biology 211, 1326-1335.

Scott, G. R., Hawkes, L. A., Frappell, P. B., Butler, P. J., Bishop, C. M. \& Milsom, W. K. (2015). How bar-headed geese fly over the Himalayas. Physiology 30, 107-115.

SERRAT, M. A. (2013). Environmental temperature impact on bone and cartilage growth. Comprehensive Physiology 4, 621-655.

Serrat, M. A., KInG, D. \& LoveJOY, C. O. (2008). Temperature regulates limb length in homeotherms by directly modulating cartilage growth. Proceedings of the National Academy of Sciences of the United States of America 105, 19348-19353. 
SERrat, M., Williams, R. \& FARNUM, C. (2010). Exercise mitigates the stunting effect of cold temperature on limb elongation in mice by increasing solute delivery to the growth plate. Journal of Applied Physiology 109, 1868-1879.

Smith, J. N. M. \& DHONDT, A. A. (1980). Experimental confirmation of heritable morphological variation in a natural population of song sparrows. Evolution 34, 1155-1158.

SMITH, T. B. (1990a). Patterns of morphological and geographic-variation in trophic bill morphs of the African Finch Pyrenestes. Biological Journal of the Linnean Society 41, 381-414.

SMITH, T. B. (1990b). Resource use by bill morphs of an African finch: Evidence for intraspecific competition. Ecology 71, 1246-1257.

SNOW, D. W. (1954). Trends in geographical variation in Palaearctic members of the genus Parus. Evolution 8, 19-28.

Steen, I., J. B. SteEn. (1965). The importance of the legs in the thermoregulation of birds. Acta Physiologica Scandinavica 63, 285-291.

StetTenheim, P. R. (2000). The integumentary morphology of modern birds - An overview. American Zoologist 40, 461-477.

SteVEnson, R. D. (1986). Allens rule in North American rabbits (Sylvilagus) and hares (Lepus) Is an exception, not a rule. Journal of Mammalogy 67, 312-316.

Swennen, C., De Bruijn, L. L. M., Duiven, P., Leopold, M. F. \& Marteijn, E. C. L. (1983). Differences in bill form of the oystercatcher Haematopus ostralegus; a dynamic adaptation to specific foraging techniques. Journal of Sea Research 17, 57-83.

Symonds, M. R. E. \& TATTERSALL, G. J. (2010). Geographical variation in bill size across bird species provides evidence for Allen's rule. American Naturalist 176, 188-197.

TARBURTON, M. K. (1989). Subspeciation in the red-tailed tropicbird. Notornis 36, 39-49.

TATTERSALL, G. J. (2016a). Infrared thermography: A non-invasive window into thermal physiology. Comp Biochem Physiol A Mol Integr Physiol. In Press. doi: 10.1016/j.cbpa.2016.02.022.

TAttersall, G. J. (2016b). Thermimage: Thermal Image Analysis. R package version 2.1, http://cran.r-project.org/package=Thermimage.

TATTERSALL, G. J. \& CADENA, V . (2010). Insights into animal temperature adaptations revealed through thermal imaging. Imaging Science Journal 58, 261-268.

TAtTERsall, G. J. \& Milsom, W. K. (2003). Transient peripheral warming accompanies the hypoxic metabolic response in the golden-mantled ground squirrel. Journal of Experimental Biology 206, 33-42.

TAtTersall, G. J. \& Milsom, W. K. (2009). Hypoxia reduces the hypothalamic thermogenic threshold and thermosensitivity. Journal of Physiology (London) 587, 5259-74.

Tattersall, G. J., Andrade, D. V. \& ABE, A. S. (2009). Heat exchange from the toucan bill reveals a controllable vascular thermal radiator. Science 325, 468-470.

Tattersall, G. J., Sinclair, B. J., Withers, P. C., Fields, P. A., Seebacher, F., Cooper, C. E. \& MALONEY, S. K. (2012). Coping with thermal challenges: Physiological adaptations to environmental temperatures. Comprehensive Physiology 2, 2151-2202.

TAYLOR, C. R. (1966). The vascularity and possible thermoregulatory function of the horns in goats. Physiological Zoology 38, 127-139.

TRAVIS, J. (1994). Evaluating the adaptive role of morphological plasticity. In Ecological Morphology (ed. P. C. Wainright and S. M. Reilly), pp. 99-121. Chicago Press, Chicago.

Twedt, D. J., BLEIER, W. J. \& LinZ, G. M. (1994). Geographic variation in yellow-headed blackbirds from the northern Great Plains. The Condor 96, 1030-1036. 
van de Pol, M., Ens, B. J., Oosterbeek, K., Brouwer, L., Verhulst, S., Tinbergen, J. M., RutTEN, A. L. \& DE JONG, M. (2009). Oystercatchers' bill shapes as a proxy for diet specialization: more differentiation than meets the eye. Ardea 97, 335-346.

VAN DER MEIJ, M. A. A. \& Bout, R. G. (2008). The relationship between shape of the skull and bite force in finches. Journal of Experimental Biology 211, 1668-1680.

Van Hemert, C., Handel, C. M., Blake, J. E., Swor, R. M. \& O'Hara, T. M. (2012). Microanatomy of passerine hard-cornified tissues: Beak and claw structure of the blackcapped chickadee (Poecile atricapillus). Journal of Morphology 273, 226-240.

VANDERWERF, E. A. (2012). Ecogeographic patterns of morphological variation in elepaios (Chasiempis spp.): Bergmann's, Allen's, and Gloger's rules in a microcosm Ornithological Monographs 73, 1-34.

Villarreal, J. A., Schlegel, W. M. \& Prange, H. D. (2007). Thermal environment affects morphological and behavioral development of Rattus norvegicus. Physiology \& Behavior 91, 26-35.

WAlsBerG, G. E. \& KING, J. R. (1978). Relationship of external surface area of birds to skin surface area and body mass. Journal of Experimental Biology 76, 185-189.

WARD, S. \& SLATER, P. J. B. (2005). Raised thermoregulatory costs at exposed song posts increase the energetic cost of singing for willow warblers Phylloscopus trochilus. Journal of Avian Biology 36, 280-286.

WARHAM, J. (1972). Breeding seasons and sexual dimorphism in rockhopper penguins. The Auk 89, 86-105.

WEAVER, M. E. \& INGRAM, D. L. (1969). Morphological changes in swine associated with environmental temperature. Ecology 50, 710-713.

WeInER, J. (1994). The beak of the finch. A story of evolution in our time. Alfred A. Knopp, Inc., New York.

Wellmann, A. E. \& Downs, C. T. (2009). A behavioural study of sleep patterns in the malachite sunbird, Cape white-eye and fan-tailed widowbird. Animal Behaviour 77, 61-66.

WeSt-EBERHARD, M. J. (2005). Developmental plasticity and the origin of species differences. Proceedings of the National Academy of Sciences of the United States of America 102, 6543-6549.

White, E. \& GitTin, J. C. (1964). The value of measurements in the study of wader migration, with particular reference to the Oystercatcher. Bird Study 11, 257-261.

WIEDENFELD, D. A. (1991). Geographical morphology of male yellow warblers. The Condor 93, 712-723.

Wolf, L. L., Stiles, F. G. \& HAinsworth, F. R. (1976). Ecological organization of a tropical, highland hummingbird community. Journal of Animal Ecology 45, 349-379.

Wu, P., JiAng, T. X., Shen, J. Y., Widelitz, R. B. \& Chuong, C. M. (2006). Morphoregulation of avian beaks: Comparative mapping of growth zone activities and morphological evolution. Developmental Dynamics 235, 1400-1412.

Wu, P., Jiang, T. X., Suksaweang, S., Widelitz, R. B. \& Chuong, C. M. (2004). Molecular shaping of the beak. Science 305, 1465-6.

YARBrough, C. (1971). The influence of distribution and ecology on the thermoregulation of small birds. Comparative Biochemistry and Physiology A 39, 235-266.

Yom-Tov, Y. \& YoM-Tov, J. (2005). Global warming, Bergmann's rule and body size in the masked shrew Sorex cinereus Kerr in Alaska. Journal of Animal Ecology 74, 803-808. 
Young, N. M., Hu, D., Lainoff, A. J., Smith, F. J., Diaz, R., Tucker, A. S., Trainor, P. A., Schneider, R. A., HAllgrimsson, B. \& MARCucio, R. S. (2014). Embryonic bauplans and the developmental origins of facial diversity and constraint. Development 141, 10591063.

ZINK, R. M. (1986). Patterns and evolutionary significance of geographic variation in the Schistacea Group of the fox sparrow (Passerella iliaca). Ornithological Monographs, iii119. 
Table 1. Bird species $\left(N_{\text {species }}=102 ; N_{\text {studies }}=110\right)$ in which geographic clines in bill size have been documented or studied intraspecifically.

\begin{tabular}{|c|c|c|c|c|c|c|}
\hline Species & Common name & $\begin{array}{l}\text { Geographic } \\
\text { scale }\end{array}$ & $\begin{array}{l}\text { Bill size } \\
\text { measure }\end{array}$ & $\begin{array}{l}\text { Covariate( } \\
\text { s) }\end{array}$ & $\begin{array}{l}\text { Support for } \\
\text { Allen's rule }\end{array}$ & Reference \\
\hline Acanthiza pusilla & Brown thornbill & Australia & Length & Latitude & No & Abbott (1974) \\
\hline $\begin{array}{l}\text { Acanthorhynchus } \\
\text { tenuirostris }\end{array}$ & Eastern spinebill & Australia & Length & Latitude & No & Abbott (1974) \\
\hline Aeronautes saxatilis & $\begin{array}{l}\text { White-throated } \\
\text { swift }\end{array}$ & North America & Length & Latitude & $\begin{array}{l}\text { No - but no } \\
\text { control for body } \\
\text { size }\end{array}$ & Behle (1973) \\
\hline Agelaius phoeniceus & $\begin{array}{l}\text { Red-winged } \\
\text { blackbird }\end{array}$ & North America & $\begin{array}{l}\text { Surface area to } \\
\text { volume ratio }\end{array}$ & $\begin{array}{l}\text { Minimum } \\
\text { April } \\
\text { temperatur } \\
\text { e }\end{array}$ & Yes & Power (1970) \\
\hline Agelaius phoeniceus & $\begin{array}{l}\text { Red-winged } \\
\text { blackbird }\end{array}$ & Florida & Length, depth & Latitude & No & $\begin{array}{l}\text { Mosimann \& James } \\
\text { (1979) }\end{array}$ \\
\hline Alisterus scapularis & $\begin{array}{l}\text { Australian king } \\
\text { parrot }\end{array}$ & Australia & Surface area & $\begin{array}{l}\text { Latitude, } \\
\text { summer } \\
\text { maximum } \\
\text { temperatur } \\
\text { e }\end{array}$ & No & $\begin{array}{l}\text { Campbell-Tennant et al. } \\
(2015)\end{array}$ \\
\hline $\begin{array}{l}\text { Anthochaera } \\
\text { carunculata }\end{array}$ & Red wattlebird & Australia & Length & Latitude & Unclear & Abbott (1974) \\
\hline $\begin{array}{l}\text { Anthochaera } \\
\text { chrysoptera }\end{array}$ & Little wattlebird & Australia & Length & Latitude & Unclear & Abbott (1974) \\
\hline Arenaria interpres & Ruddy turnstone & Australia & Length & Locality & Yes & Nebel et al. (2013) \\
\hline
\end{tabular}




\begin{tabular}{|c|c|c|c|c|c|c|}
\hline Branta canadensis & Canada goose & Canada & Length & Locality & No & Leafloor et al. (1998) \\
\hline Calidris acuminate & $\begin{array}{l}\text { Sharp-tailed } \\
\text { sandpiper }\end{array}$ & Australia & Length & Locality & No & Nebel et al. (2013) \\
\hline Calidris alba & Sanderling & Australia & Length & Locality & Yes & Nebel et al. (2013) \\
\hline Calidris canutus & Red knot & Australia & Length & Locality & No & Nebel et al. (2013) \\
\hline Calidris ferruginea & $\begin{array}{l}\text { Curlew } \\
\text { sandpiper }\end{array}$ & Australia & Length & Locality & Yes & Nebel et al. (2013) \\
\hline Calidris mauri & $\begin{array}{l}\text { Western } \\
\text { sandpiper }\end{array}$ & Americas & Length & Latitude & Yes & Nebel (2005) \\
\hline Calidris pusilla & $\begin{array}{l}\text { Semipalmated } \\
\text { Sandpiper }\end{array}$ & Canada, Alaska & Length & Latitude & Yes & $\begin{array}{l}\text { Gratto-Trevor et al. } \\
\text { (2012) }\end{array}$ \\
\hline Calidris ruficollis & Red-necked stint & Australia & Length & Locality & No & Nebel et al. (2013) \\
\hline Calidris tenuirostris & Great knot & Australia & Length & Locality & Yes & Nebel et al. (2013) \\
\hline $\begin{array}{l}\text { Callocephalon } \\
\text { fimbriatum }\end{array}$ & $\begin{array}{l}\text { Gang-gang } \\
\text { cockatoo }\end{array}$ & Australia & Surface area & $\begin{array}{l}\text { Latitude, } \\
\text { summer } \\
\text { maximum } \\
\text { temperatur } \\
\text { e }\end{array}$ & No & $\begin{array}{l}\text { Campbell-Tennant et al. } \\
\text { (2015) }\end{array}$ \\
\hline Carduelis chloris & $\begin{array}{l}\text { European } \\
\text { greenfinch }\end{array}$ & Europe & $\begin{array}{l}\text { Length, width, } \\
\text { depth }\end{array}$ & Latitude & Yes & Merilä (1997) \\
\hline $\begin{array}{l}\text { Carpodacus } \\
\text { mexicanus }\end{array}$ & House finch & North America & Length & Locality & No & Hill (1993) \\
\hline Chamaea fasciata & Wrentit & California & Length & Locality & Yes & Bowers (1960) \\
\hline $\begin{array}{l}\text { Charadrius } \\
\text { leschenaultia }\end{array}$ & $\begin{array}{l}\text { Greater sand } \\
\text { plover }\end{array}$ & Australia & Length & Locality & Yes & Nebel et al. (2013) \\
\hline Charadrius & Lesser sand & Australia & Length & Locality & Yes & Nebel et al. (2013) \\
\hline
\end{tabular}




\begin{tabular}{|c|c|c|c|c|c|c|}
\hline mongolus & plover & & & & & \\
\hline Charadrius ruficollis & $\begin{array}{l}\text { Tawny-throated } \\
\text { dotterel }\end{array}$ & Australia & Length & Locality & Yes & Nebel et al. (2013) \\
\hline $\begin{array}{l}\text { Chasiempis } \\
\text { sandwichensis }\end{array}$ & Hawaii elepaio & Hawaii & Length & Elevation & Yes & VanderWerf (2012) \\
\hline Cinclus cinclus & $\begin{array}{l}\text { White-throated } \\
\text { dipper }\end{array}$ & Spain, Portugal & Length & $\begin{array}{l}\text { Mean } \\
\text { annual } \\
\text { temperatur } \\
\text { e over time } \\
\text { (not space) }\end{array}$ & Yes, indirectly & $\begin{array}{l}\text { Moreno-Rueda \& Rivas } \\
\text { (2007) }\end{array}$ \\
\hline $\begin{array}{l}\text { Cladorhynchus } \\
\text { leucocephalus }\end{array}$ & Banded stilt & Australia & Length & Locality & No & Nebel et al. (2013) \\
\hline Coereba flaveola & Bananaquit & Jamaica & Length & Altitude & $\begin{array}{l}\text { No - but no } \\
\text { control for body } \\
\text { size }\end{array}$ & Diamond (1973) \\
\hline Columba livia & Rock dove & $\begin{array}{l}\text { Europe, Middle } \\
\text { East, Africa }\end{array}$ & Length, Width & Latitude & Yes & Johnston (1992) \\
\hline Coturnix japonica & Japanese quail & Captive & $\begin{array}{l}\text { Length, width, } \\
\text { depth PCs } \\
\text { (principal } \\
\text { components) }\end{array}$ & $\begin{array}{l}\text { Temperatu } \\
\text { re }\end{array}$ & Yes & Burness et al. (2013) \\
\hline Dendroica petechia & $\begin{array}{l}\text { American } \\
\text { yellow warbler }\end{array}$ & $\begin{array}{l}\text { Americas and } \\
\text { Caribbean }\end{array}$ & Length, width & $\begin{array}{l}\text { Temperatu } \\
\text { re }\end{array}$ & Yes & Wiedenfeld (1991) \\
\hline $\begin{array}{l}\text { Dendroica } \\
\text { townsendi }\end{array}$ & $\begin{array}{l}\text { Townsend } \\
\text { warbler }\end{array}$ & $\begin{array}{l}\text { North America } \\
\text { and Mexico }\end{array}$ & $\begin{array}{l}\text { Length, width, } \\
\text { depth }\end{array}$ & Locality & No & Morrison (1983) \\
\hline Diglossa carbonaria & $\begin{array}{l}\text { Grey-bellied } \\
\text { flowerpiercer }\end{array}$ & $\begin{array}{l}\text { Central \& South } \\
\text { America }\end{array}$ & Length & Latitude & $\begin{array}{l}\text { No - but no } \\
\text { control for body } \\
\text { size }\end{array}$ & Graves (1991) \\
\hline Embernagra & Pampa finch & Southern South & Length, width & Latitude, & Yes & Hayes (2003) \\
\hline
\end{tabular}




\begin{tabular}{|c|c|c|c|c|c|c|}
\hline platensis & & America & & altitude & & \\
\hline Eopsaltria australis & $\begin{array}{l}\text { Eastern yellow } \\
\text { robin }\end{array}$ & Australia & Length & Latitude & Unclear & Abbott (1974) \\
\hline Epthianura albifrons & $\begin{array}{l}\text { White-fronted } \\
\text { chat }\end{array}$ & Australia & Length & Locality & $\begin{array}{l}\text { No - but no } \\
\text { control for body } \\
\text { size }\end{array}$ & Major (2012) \\
\hline Eremophila alpestris & Horned lark & South-west USA & Length & $\begin{array}{l}\text { Summer } \\
\text { temperatur } \\
\mathrm{e}\end{array}$ & No & Niles (1973) \\
\hline $\begin{array}{l}\text { Erythrogonys } \\
\text { cinctus }\end{array}$ & $\begin{array}{l}\text { Red-kneed } \\
\text { dotterel }\end{array}$ & Australia & Length & Locality & Yes & Nebel et al. (2013) \\
\hline $\begin{array}{l}\text { Eudyptes } \\
\text { chrysosome }\end{array}$ & $\begin{array}{l}\text { Southern } \\
\text { rockhopper } \\
\text { penguin }\end{array}$ & $\begin{array}{l}\text { New Zealand } \\
\text { islands }\end{array}$ & $\begin{array}{l}\text { Length, width, } \\
\text { depth }\end{array}$ & Locality & Yes & Warham (1972) \\
\hline Falco peregrinus & Peregrine falcon & Global & Volume & Locality & Yes, indirectly & Johansson et al. (1998) \\
\hline Fringilla coelobs & $\begin{array}{l}\text { Common } \\
\text { chaffinch }\end{array}$ & $\begin{array}{l}\text { Canary Islands, } \\
\text { North Africa, } \\
\text { Azores }\end{array}$ & $\begin{array}{l}\text { Length, width, } \\
\text { depth }\end{array}$ & $\begin{array}{l}\text { Temperatu } \\
\text { re }\end{array}$ & No & Grant (1979b) \\
\hline Gymnorhina tibicen & $\begin{array}{l}\text { Australian } \\
\text { magpie }\end{array}$ & Australia & Length & Latitude & No & Abbott (1974) \\
\hline $\begin{array}{l}\text { Haematopus } \\
\text { fuliginosus }\end{array}$ & $\begin{array}{l}\text { Sooty } \\
\text { oystercatcher }\end{array}$ & Australia & Length & Locality & No & Nebel et al. (2013) \\
\hline $\begin{array}{l}\text { Haematopus } \\
\text { longirostris }\end{array}$ & $\begin{array}{l}\text { Pied } \\
\text { oystercatcher }\end{array}$ & Australia & Length & Locality & Yes & Nebel et al. (2013) \\
\hline $\begin{array}{l}\text { Henicorhina } \\
\text { leucophrys }\end{array}$ & $\begin{array}{l}\text { Grey-breasted } \\
\text { wood wren }\end{array}$ & Colombia & $\begin{array}{l}\text { Length, width, } \\
\text { depth, PCs }\end{array}$ & Altitude & Yes & Caro et al. (2013) \\
\hline $\begin{array}{l}\text { Himantopus } \\
\text { himantopus }\end{array}$ & $\begin{array}{l}\text { Black-winged } \\
\text { stilt }\end{array}$ & Australia & Length & Locality & Yes & Nebel et al. (2013) \\
\hline
\end{tabular}




\begin{tabular}{|c|c|c|c|c|c|c|}
\hline Junco hyemalis & Dark-eyed junco & Canada & $\begin{array}{l}\text { Length, width, } \\
\text { depth }\end{array}$ & Elevation & $\begin{array}{l}\text { Yes - but } \\
\text { females only }\end{array}$ & Bears et al. (2008) \\
\hline Leptodon forbesi & $\begin{array}{l}\text { White-collared } \\
\text { kite }\end{array}$ & Brazil & Length, width & Latitude & $\begin{array}{l}\text { No - but no } \\
\text { control for body } \\
\text { size }\end{array}$ & Dénes et al. (2011) \\
\hline Limosa fedoa & Marbled godwit & North America & Length & Locality & Yes & Gibson \& Kessel (1989) \\
\hline Limosa lapponica & $\begin{array}{l}\text { Bar-tailed } \\
\text { godwit }\end{array}$ & $\begin{array}{l}\text { Alaska, New } \\
\text { Zealand }\end{array}$ & Length & Latitude & Yes & Conklin et al. (2011) \\
\hline Malurus cyaneus & $\begin{array}{l}\text { Superb } \\
\text { fairywren }\end{array}$ & Australia & Length & Latitude & No & Abbott (1974) \\
\hline $\begin{array}{l}\text { Melanerpes } \\
\text { formicivorus }\end{array}$ & $\begin{array}{l}\text { Acorn } \\
\text { woodpecker }\end{array}$ & Americas & $\begin{array}{l}\text { Length, width, } \\
\text { depth }\end{array}$ & Locality & No & Benítez-Díez (1993) \\
\hline Meliphaga leucotis & $\begin{array}{l}\text { White-eared } \\
\text { honeyeater }\end{array}$ & Australia & Length & Latitude & No & Abbott (1974) \\
\hline Melospiza melodia & Song Sparrow & North America & Surface area & $\begin{array}{l}\text { Maximum } \\
\text { summer } \\
\text { temperatur } \\
\text { e, latitude }\end{array}$ & Yes & Greenberg et al. (2012) \\
\hline Melospiza melodia & Song Sparrow & North America & Surface area & $\begin{array}{l}\text { Minimum } \\
\text { winter } \\
\text { temperatur } \\
\text { e, distance } \\
\text { from coast }\end{array}$ & Yes & $\begin{array}{l}\text { Danner \& Greenberg } \\
\text { (2015) }\end{array}$ \\
\hline Merganetta armata & Torrent Duck & South America & Length & $\begin{array}{l}\text { Temperatu } \\
\text { re, latitude, } \\
\text { elevation }\end{array}$ & Yes & $\begin{array}{l}\text { Gutiérrez-Pinto et al. } \\
\text { (2014) }\end{array}$ \\
\hline $\begin{array}{l}\text { Numenius } \\
\text { madagascariensis }\end{array}$ & $\begin{array}{l}\text { Far Eastern } \\
\text { Curlew }\end{array}$ & Australia & Length & Locality & Yes & Nebel et al. (2013) \\
\hline Oceanodroma & Leach's Storm & North America & Length, depth & Locality & No & Power \& Ainley (1986) \\
\hline
\end{tabular}




\begin{tabular}{|c|c|c|c|c|c|c|}
\hline leucorhoa & Petrel & & & & & \\
\hline Otus asio & $\begin{array}{l}\text { Eastern Screech } \\
\text { Owl }\end{array}$ & North America & Length & Latitude & Yes & Gehlbach (2003) \\
\hline Otus kennicottii & $\begin{array}{l}\text { Western Screech } \\
\text { Owl }\end{array}$ & North America & Length & Latitude & Yes & Gehlbach (2003) \\
\hline $\begin{array}{l}\text { Paradoxornis } \\
\text { webbianus }\end{array}$ & $\begin{array}{l}\text { Vinous-throated } \\
\text { Parrotbill }\end{array}$ & China & $\begin{array}{l}\text { Length, width, } \\
\text { depth PCs }\end{array}$ & Elevation & No & Hsu et al. (2013) \\
\hline Parus atricapillus & $\begin{array}{l}\text { Black-capped } \\
\text { Chickadee }\end{array}$ & Palaearctic & Length & $\begin{array}{l}\text { Mean } \\
\text { winter } \\
\text { temperatur } \\
\text { e }\end{array}$ & Yes & Snow (1954) \\
\hline Parus caeruleus & $\begin{array}{l}\text { Eurasian Blue } \\
\text { Tit }\end{array}$ & Palaearctic & Length & $\begin{array}{l}\text { Mean } \\
\text { winter } \\
\text { temperatur } \\
\text { e }\end{array}$ & Yes & Snow (1954) \\
\hline Parus caeruleus & $\begin{array}{l}\text { Eurasian Blue } \\
\text { Tit }\end{array}$ & Canary Islands & $\begin{array}{l}\text { Length, width } \\
\text { and depth }\end{array}$ & Longitude & Yes & Grant (1979a) \\
\hline Parus caeruleus & $\begin{array}{l}\text { Eurasian Blue } \\
\text { Tit }\end{array}$ & $\begin{array}{l}\text { Canary Islands, } \\
\text { North Africa, } \\
\text { England }\end{array}$ & Length, depth & Locality & Yes & $\begin{array}{l}\text { Partridge \& Pring-Mill } \\
\text { (1977) }\end{array}$ \\
\hline Parus caeruleus & $\begin{array}{l}\text { Eurasian Blue } \\
\text { Tit }\end{array}$ & Europe & Length, depth & Locality & Unclear & Martin (1991) \\
\hline Parus major & Great Tit & Palaearctic & Length & $\begin{array}{l}\text { Mean } \\
\text { winter } \\
\text { temperatur } \\
\mathrm{e}\end{array}$ & Yes & Snow (1954) \\
\hline Parus palustris & Marsh Tit & Palaearctic & Length & $\begin{array}{l}\text { Mean } \\
\text { winter } \\
\text { temperatur } \\
\mathrm{e}\end{array}$ & Yes & Snow (1954) \\
\hline
\end{tabular}




\begin{tabular}{|c|c|c|c|c|c|c|}
\hline Passer domesticus & House Sparrow & Western Europe & Length & $\begin{array}{l}\text { Latitude, } \\
\text { mean } \\
\text { January } \\
\text { and July } \\
\text { temperatur } \\
\text { es }\end{array}$ & Yes & Johnston (1969) \\
\hline Passer domesticus & House Sparrow & $\begin{array}{l}\text { Americas, } \\
\text { Europe }\end{array}$ & Length, width & Latitude & Yes & $\begin{array}{l}\text { Johnston \& Selander } \\
\text { (1973) }\end{array}$ \\
\hline $\begin{array}{l}\text { Passer } \\
\text { hispaniolensis }\end{array}$ & Spanish Sparrow & Western Europe & Length & $\begin{array}{l}\text { Latitude, } \\
\text { mean } \\
\text { January } \\
\text { and July } \\
\text { temperatur } \\
\text { es }\end{array}$ & Yes & Johnston (1969) \\
\hline $\begin{array}{l}\text { Passerculus } \\
\text { sandwichensis }\end{array}$ & $\begin{array}{l}\text { Savannah } \\
\text { Sparrow }\end{array}$ & North America & Length, depth & $\begin{array}{l}\text { Mean } \\
\text { winter } \\
\text { temperatur } \\
\mathrm{e}\end{array}$ & Yes & Rising (1987) \\
\hline $\begin{array}{l}\text { Passerculus } \\
\text { sandwichensis }\end{array}$ & $\begin{array}{l}\text { Savannah } \\
\text { Sparrow }\end{array}$ & North America & $\begin{array}{l}\text { PC bill } \\
\text { dimensions }\end{array}$ & $\begin{array}{l}\text { Average } \\
\text { winter } \\
\text { temperatur } \\
\mathrm{e}\end{array}$ & Yes & Rising (1988) \\
\hline $\begin{array}{l}\text { Passerculus } \\
\text { sandwichensis }\end{array}$ & $\begin{array}{l}\text { Savannah } \\
\text { Sparrow }\end{array}$ & North America & Surface area & $\begin{array}{l}\text { Maximum } \\
\text { summer } \\
\text { temperatur } \\
\text { e, latitude }\end{array}$ & Yes & Greenberg et al. (2012) \\
\hline Passerella iliaca & $\begin{array}{l}\text { Red Fox } \\
\text { Sparrow }\end{array}$ & North America & $\begin{array}{l}\text { Length, width, } \\
\text { depth }\end{array}$ & Locality & Yes & Zink (1986) \\
\hline Petroica cucullata & Hooded Robin & Australia & Length & Latitude & No & Abbott (1974) \\
\hline $\begin{array}{l}\text { Phaethon } \\
\text { rubricauda }\end{array}$ & $\begin{array}{l}\text { Red-tailed } \\
\text { Tropicbird }\end{array}$ & Pacific Islands & Length & Latitude & $\begin{array}{l}\text { Unclear - yes in } \\
\text { Northern } \\
\text { Hemisphere; no } \\
\text { in Southern }\end{array}$ & Tarburton (1989) \\
\hline
\end{tabular}




\begin{tabular}{|c|c|c|c|c|c|c|}
\hline & & & & & Hemisphere & \\
\hline $\begin{array}{l}\text { Phylidonyris } \\
\text { novaehollandiae }\end{array}$ & $\begin{array}{l}\text { New Holland } \\
\text { Honeyeater }\end{array}$ & Australia & Length & Latitude & No & Abbott (1974) \\
\hline $\begin{array}{l}\text { Phylidonyris } \\
\text { pyrrhoptera }\end{array}$ & $\begin{array}{l}\text { Crescent } \\
\text { Honeyeater }\end{array}$ & Australia & Length & Latitude & Yes & Abbott (1974) \\
\hline Picoides borealis & $\begin{array}{l}\text { Red-cockaded } \\
\text { Woodpecker }\end{array}$ & $\begin{array}{l}\text { South-eastern } \\
\text { USA }\end{array}$ & Length & Latitude & Yes & $\begin{array}{l}\text { Mengel \& Jackson } \\
\text { (1977) }\end{array}$ \\
\hline Pinicola enucleata & Pine Grosbeak & North America & Length, depth & $\begin{array}{l}\text { Latitude, } \\
\text { longitude, } \\
\text { mean } \\
\text { January } \\
\text { temperatur } \\
\text { e }\end{array}$ & Yes & Adkisson (1981) \\
\hline Platycercus elegans & Crimson Rosella & Australia & Surface area & $\begin{array}{l}\text { Latitude, } \\
\text { summer } \\
\text { maximum } \\
\text { temperatur } \\
\text { e }\end{array}$ & Yes & $\begin{array}{l}\text { Campbell-Tennant et al. } \\
\text { (2015) }\end{array}$ \\
\hline Pluvialis fulva & $\begin{array}{l}\text { Pacific Golden } \\
\text { Plover }\end{array}$ & Australia & Length & Locality & No & Nebel et al. (2013) \\
\hline Pluvialis squaterola & Grey Plover & Australia & Length & Locality & Yes & Nebel et al. (2013) \\
\hline $\begin{array}{l}\text { Pogoniulus } \\
\text { bilineatus }\end{array}$ & $\begin{array}{l}\text { Yellow-rumped } \\
\text { Tinkerbird }\end{array}$ & Central Africa & $\begin{array}{l}\text { Length, width, } \\
\text { depth PC }\end{array}$ & Altitude & $\begin{array}{l}\text { No - but no } \\
\text { control for body } \\
\text { size }\end{array}$ & Kirschel et al. (2009) \\
\hline $\begin{array}{l}\text { Pogoniulus } \\
\text { subsulphureus }\end{array}$ & $\begin{array}{l}\text { Yellow-throated } \\
\text { Tinkerbird }\end{array}$ & Central Africa & $\begin{array}{l}\text { Length, width, } \\
\text { depth PC }\end{array}$ & Altitude & $\begin{array}{l}\text { No - but no } \\
\text { control for body } \\
\text { size }\end{array}$ & Kirschel et al. (2009) \\
\hline $\begin{array}{l}\text { Psephotus } \\
\text { haematonotus }\end{array}$ & $\begin{array}{l}\text { Red-rumped } \\
\text { Parrot }\end{array}$ & Australia & Surface area & $\begin{array}{l}\text { Latitude, } \\
\text { summer } \\
\text { maximum } \\
\text { temperatur }\end{array}$ & Yes & $\begin{array}{l}\text { Campbell-Tennant et al. } \\
\text { (2015) }\end{array}$ \\
\hline
\end{tabular}




\begin{tabular}{|c|c|c|c|c|c|c|}
\hline & & & & $\mathrm{e}$ & & \\
\hline Psephotus varius & Mulga Parrot & Australia & Surface area & $\begin{array}{l}\text { Latitude, } \\
\text { summer } \\
\text { maximum } \\
\text { temperatur } \\
\text { e }\end{array}$ & Yes & $\begin{array}{l}\text { Campbell-Tennant et al. } \\
\text { (2015) }\end{array}$ \\
\hline Pycnonotus jocosus & $\begin{array}{l}\text { Red-whiskered } \\
\text { Bulbul }\end{array}$ & Reunion Island & $\begin{array}{l}\text { Length, width, } \\
\text { depth }\end{array}$ & $\begin{array}{l}\text { Locality, } \\
\text { temperatur } \\
\text { e, humidity }\end{array}$ & No & Amiot et al. (2007) \\
\hline Pyrenestes minor & $\begin{array}{l}\text { Lesser } \\
\text { Seedcracker }\end{array}$ & East Africa & $\begin{array}{l}\text { Length, width, } \\
\text { depth }\end{array}$ & Rainfall & Yes & Smith (1990) \\
\hline Pyrenestes ostrinus & $\begin{array}{l}\text { Black-bellied } \\
\text { Seedcracker }\end{array}$ & East Africa & $\begin{array}{l}\text { Length, width, } \\
\text { depth }\end{array}$ & Rainfall & Yes & Smith (1990) \\
\hline $\begin{array}{l}\text { Pyrenestes } \\
\text { sanguineus }\end{array}$ & $\begin{array}{l}\text { Crimson } \\
\text { Seedcracker }\end{array}$ & East Africa & $\begin{array}{l}\text { Length, width, } \\
\text { depth }\end{array}$ & Rainfall & Yes & Smith (1990) \\
\hline $\begin{array}{l}\text { Pyrrhocorax } \\
\text { graculus }\end{array}$ & Alpine Chough & $\begin{array}{l}\text { Palaearctic, } \\
\text { North Africa }\end{array}$ & $\begin{array}{l}\text { Length, width } \\
\text { and depth }\end{array}$ & $\begin{array}{l}\text { Latitude, } \\
\text { temperatur } \\
\mathrm{e}\end{array}$ & Yes & $\begin{array}{l}\text { Laiolo \& Rolando } \\
\text { (2001) }\end{array}$ \\
\hline $\begin{array}{l}\text { Pyrrhocorax } \\
\text { pyrrhocorax }\end{array}$ & $\begin{array}{l}\text { Red-billed } \\
\text { Chough }\end{array}$ & $\begin{array}{l}\text { Palaearctic, } \\
\text { North Africa }\end{array}$ & $\begin{array}{l}\text { Length, width } \\
\text { and depth }\end{array}$ & $\begin{array}{l}\text { Latitude, } \\
\text { temperatur } \\
\text { e }\end{array}$ & Yes & $\begin{array}{l}\text { Laiolo \& Rolando } \\
\text { (2001) }\end{array}$ \\
\hline $\begin{array}{l}\text { Recurvirostra } \\
\text { novaehollandiae }\end{array}$ & $\begin{array}{l}\text { Red-necked } \\
\text { Avocet }\end{array}$ & Australia & Length & Locality & No & Nebel et al. (2013) \\
\hline Sericornis frontalis & $\begin{array}{l}\text { White-browed } \\
\text { Scrubwren }\end{array}$ & Australia & Length & Latitude & No & Abbott (1974) \\
\hline Setophaga petechia & $\begin{array}{l}\text { Mangrove } \\
\text { Warbler }\end{array}$ & $\begin{array}{l}\text { Central and } \\
\text { South America, } \\
\text { Caribbean }\end{array}$ & Surface area & $\begin{array}{l}\text { Summer } \\
\text { maximum } \\
\text { temperatur } \\
\mathrm{e}\end{array}$ & Yes & $\begin{array}{l}\text { Luther \& Greenberg } \\
\text { (2014) }\end{array}$ \\
\hline
\end{tabular}




\begin{tabular}{|c|c|c|c|c|c|c|}
\hline Strepera graculina & Pied Currawong & Australia & Length & Latitude & Yes & Abbott (1974) \\
\hline Sturnus vulgaris & $\begin{array}{l}\text { Common } \\
\text { Starling }\end{array}$ & Australia & Length & $\begin{array}{l}\text { Latitude, } \\
\text { summer } \\
\text { maximum } \\
\text { temperatur } \\
\text { e, rainfall }\end{array}$ & Yes & Cardilini et al. (2016) \\
\hline Telespyza cantans & Laysan Finch & Hawaiian islands & $\begin{array}{l}\text { Length, width, } \\
\text { depth }\end{array}$ & Locality & Unclear & Conant (1988) \\
\hline Tringa brevipes & $\begin{array}{l}\text { Grey-tailed } \\
\text { Tattler }\end{array}$ & Australia & Length & Locality & No & Nebel et al. (2013) \\
\hline Tringa nebularia & $\begin{array}{l}\text { Common } \\
\text { Greenshank }\end{array}$ & Australia & Length & Locality & No & Nebel et al. (2013) \\
\hline Turdus migratorius & American Robin & North America & Length & Locality & No & Aldrich \& James (1991) \\
\hline Vanellus miles & $\begin{array}{l}\text { Masked } \\
\text { Lapwing }\end{array}$ & Australia & Length & Locality & Yes & Nebel et al. (2013) \\
\hline Vireo griseus & $\begin{array}{l}\text { White-eyed } \\
\text { Vireo }\end{array}$ & North America & Length & Locality & $\begin{array}{l}\text { No - but no } \\
\text { control for body } \\
\text { size }\end{array}$ & Hamilton (1958) \\
\hline Vireo huttoni & Hutton's Vireo & North America & Length & Locality & $\begin{array}{l}\text { No - but no } \\
\text { control for body } \\
\text { size }\end{array}$ & Hamilton (1958) \\
\hline Vireo solitaries & Solitary Vireo & North America & Length & Locality & $\begin{array}{l}\text { No - but no } \\
\text { control for body } \\
\text { size }\end{array}$ & Hamilton (1958) \\
\hline $\begin{array}{l}\text { Xanthocephalus } \\
\text { xanthocephalus }\end{array}$ & $\begin{array}{l}\text { Yellow-headed } \\
\text { Blackbird }\end{array}$ & North America & Length & Latitude & $\begin{array}{l}\text { No - but no } \\
\text { control for body } \\
\text { size }\end{array}$ & Twedt et al. (1994) \\
\hline Zonotrichia capensis & $\begin{array}{l}\text { Rufous-collared } \\
\text { Sparrow }\end{array}$ & $\begin{array}{l}\text { Central \& South } \\
\text { America }\end{array}$ & $\begin{array}{l}\text { Length, width, } \\
\text { depth, volume }\end{array}$ & Latitude & Yes & Handford (1983) \\
\hline
\end{tabular}




\section{Figure Legends}

Fig. 1. Diversity in size and shape of beaks underlies their role in resource acquisition. Depicted in this historical hand-drawing are 50 avian and two non-avian examples $(\# 51,52)$ of beaks or bills (drawing from Larousse \& Augé, 1928).

Fig. 2. Avian bills are composed of underlying bony structures (top, radiograph) overlaid with layers of dermal and epidermal structures (lower panels, A and B depict the upper and lower bill structures, respectively, in sagittal and cross section). The outer layer, the stratum corneum overlies the nourishing thinner stratum germinativum. Note the presence of capillaries within the dermis. Figures used with permission (Van Hemert et al., 2012).

Fig. 3. Cranio-facial vasculature of the herring gull (Larus argentatus), (A) with emphasis on superficial vessels, and (B) with superficial vessels removed. Arteries are shown in black, veins in grey. Adapted from Midtgård (1984b).

Fig. 4. Rapid vasomotion in bar-headed goose bills during exposure to a heat load to the body. Frames a-f represent infrared thermal images taken $30 \mathrm{~s}$ apart showing a rapid and large change in surface temperatures $\left(\sim 10^{\circ} \mathrm{C}\right.$ change from minimum to maximum) (images derived from data in Scott et al., 2008).

Fig. 5. Relationship (partial residual plots, accounting for body size and phylogeny) between bill length and minimum monthly temperature $\left(T_{\min }\right)$ among the bird families used in Symonds \& Tattersall (2010). Significantly positive relationships were observed in seven out of eight of the 
groups examined (only the Australian Estrildidae did not show support). Best-fit lines are indicated for each group. Residuals were calculated across all 214 species. Figure redrawn from data in Symonds \& Tattersall (2010).

Fig. 6. Bill size in saltmarsh sparrows depends on the season of measurement, and correlates strongly with breeding season temperature but not with winter temperature. The left two panels are the mean July high temperature versus mean breeding season bill surface area in males and females of saltmarsh sparrow taxa (Ammodramus, Melospiza, and Passerculus). The right two panels are the mean January low temperature versus mean winter bill surface area in males and females. Figure redrawn from data in Greenberg et al. (2012b). Abbreviations refer to the following taxa: M.m.a., Atlantic song sparrow Melospiza melodia atlantica; M.m.p., Alameda song sparrow M. m. pusillula; M.m.s., San Pablo song sparrow M. m. samuelis; M.m.m., Susuin song sparrow M. m. maxillaris; P.s.r., large-billed savannah sparrow Passerculus sandwichensis rostratus; P.s.b., Belding's savannah sparrow P. s. beldingi; A.n.s., Acadian Nelson's sparrow A. nelson subvirgatus; A.c., saltmarsh sparrow A. caudacutus; A.m.m., Atlantic seaside sparrow A. maritmus maritimus; A.m.f., Gulf Coast seaside sparrow A. m. fisheri.

Fig. 7. Relationship between relative bill size and year of collection for four species of Australian parrot demonstrating increases in bill size over the past 140 years. (A) Mulga parrot (Psephotus varius) (filled triangles) and red-rumped parrot (Psephotus haematonotus) (open squares); (B) gang-gang cockatoo (Callocephalon fimbriatum); and (C) crimson rosella (Platycercus elegans) males. Redrawn from Campbell-Tennant et al. (2015). 
Fig. 8. Heat transfer model predictions from the bill surface normalised to basal heat production (basal metabolic rate, BMR) scale negatively with body mass. The gradient for heat transfer $\left(T_{\mathrm{s}}-\right.$ $T_{\text {a }}$ ) was set to three different levels $\left(1,5\right.$, and $10^{\circ} \mathrm{C}$; solid lines), leading to high variation in heat transfer estimates. The dashed line indicates the ratio of bill surface area:body mass, to demonstrate that blood flow to the bill surface allows the bill to disproportionately transfer heat beyond morphological predictions. See text for details of calculations. Note: under high solar radiation, larger surface areas will exhibit heat gain (not shown here), making this comparison appropriate from the perspective of heat balance at thermoneutral temperatures. 


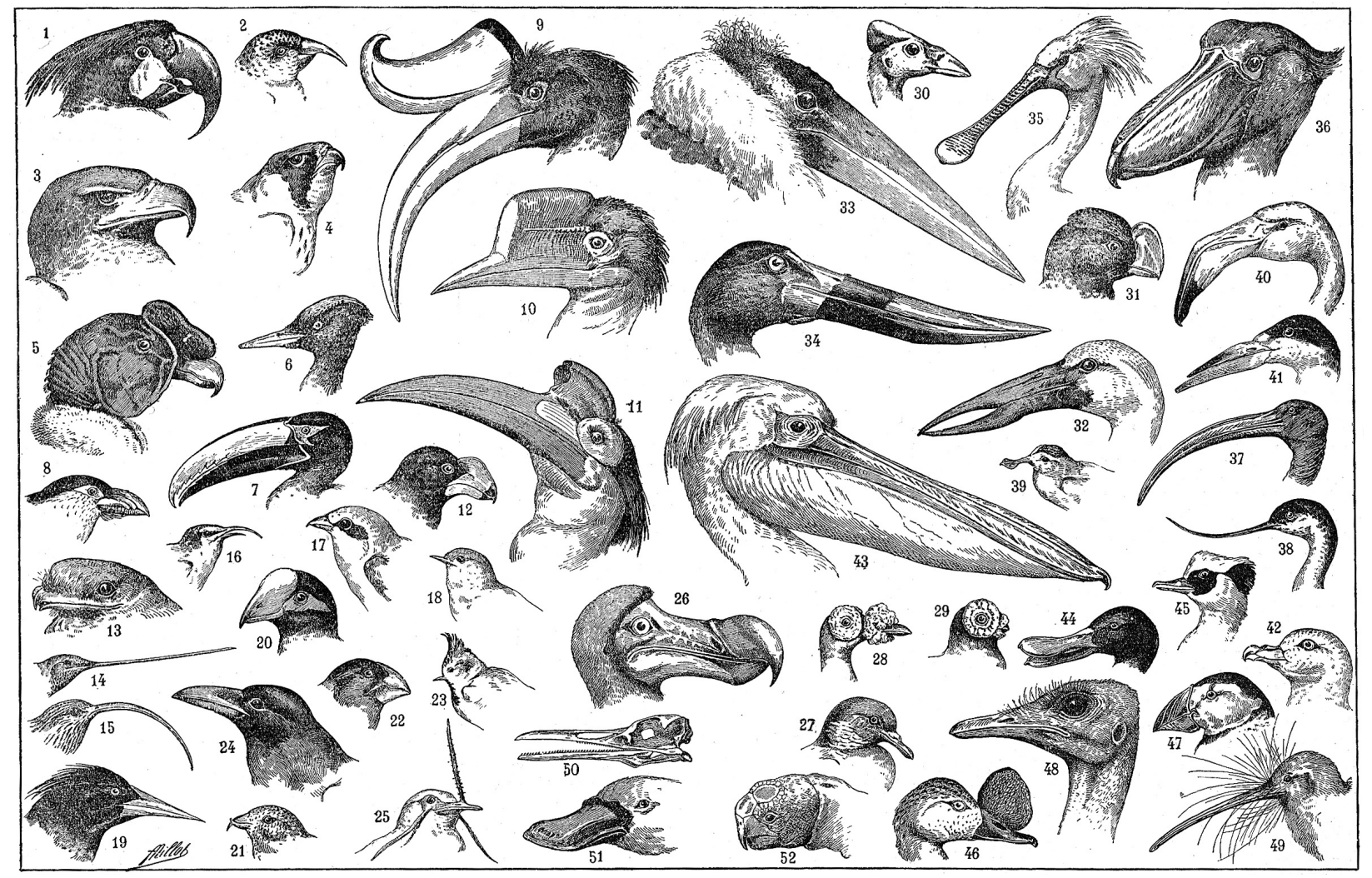

Figure 1. 


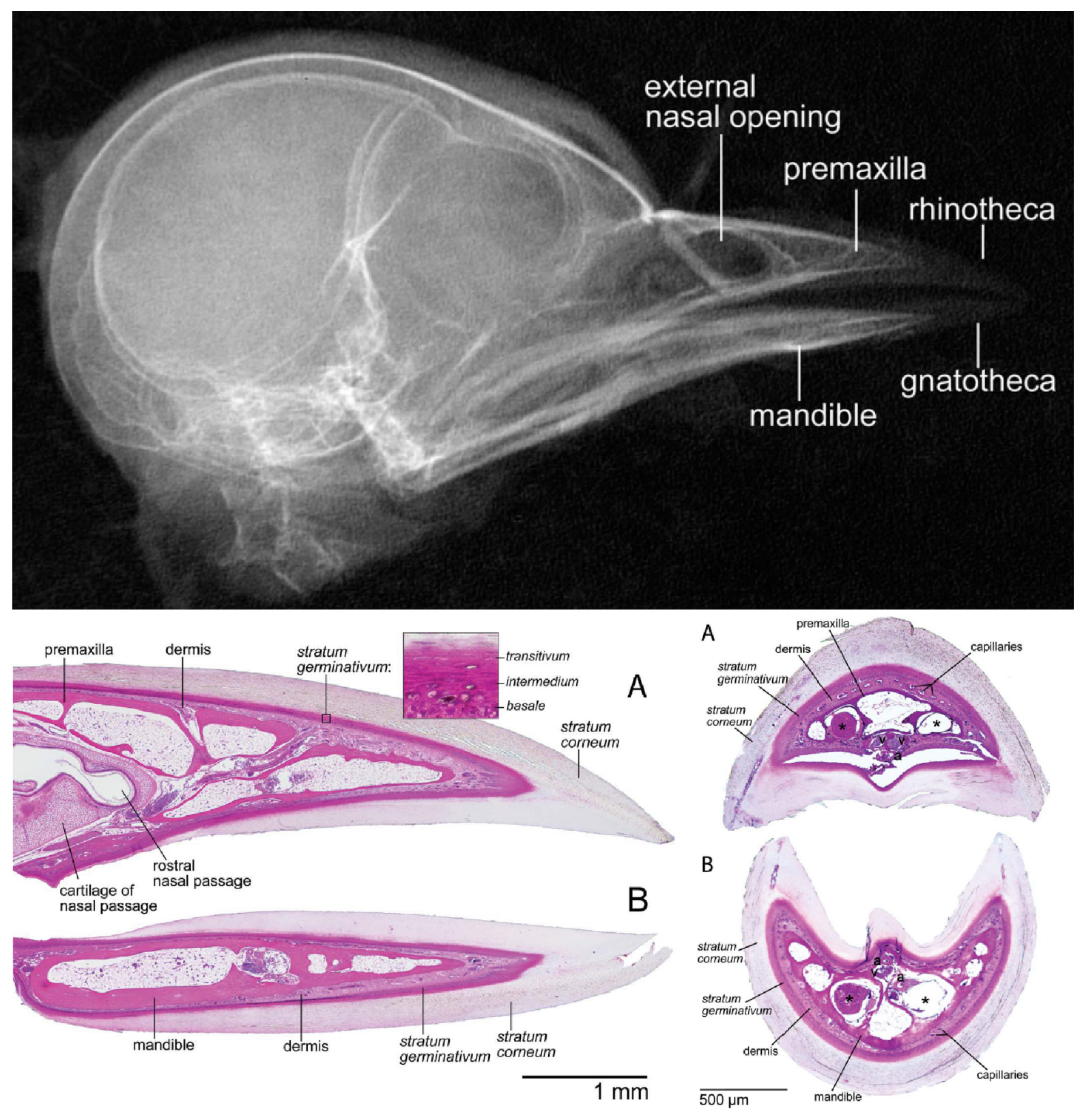

Figure 2. 

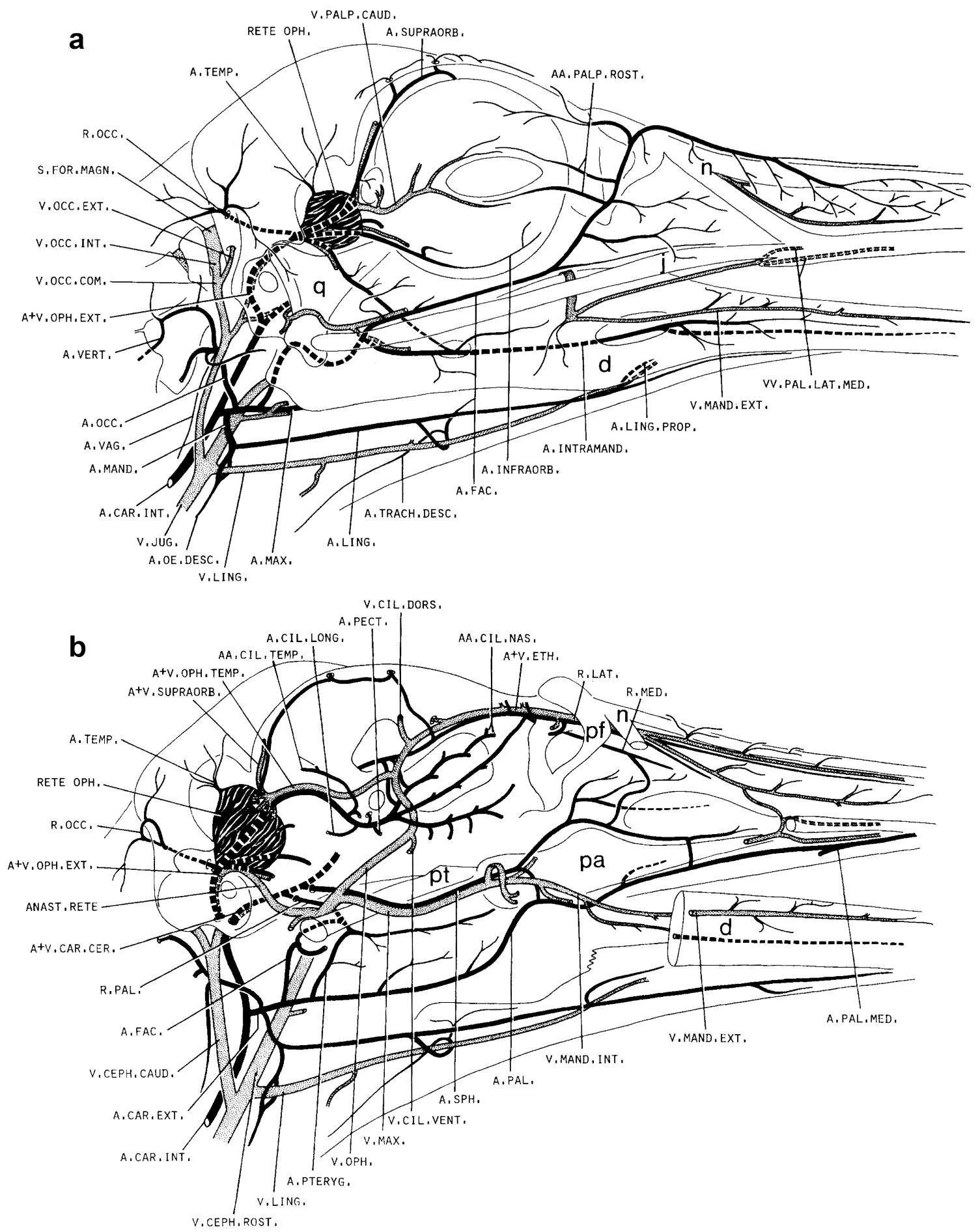

Figure 3. 


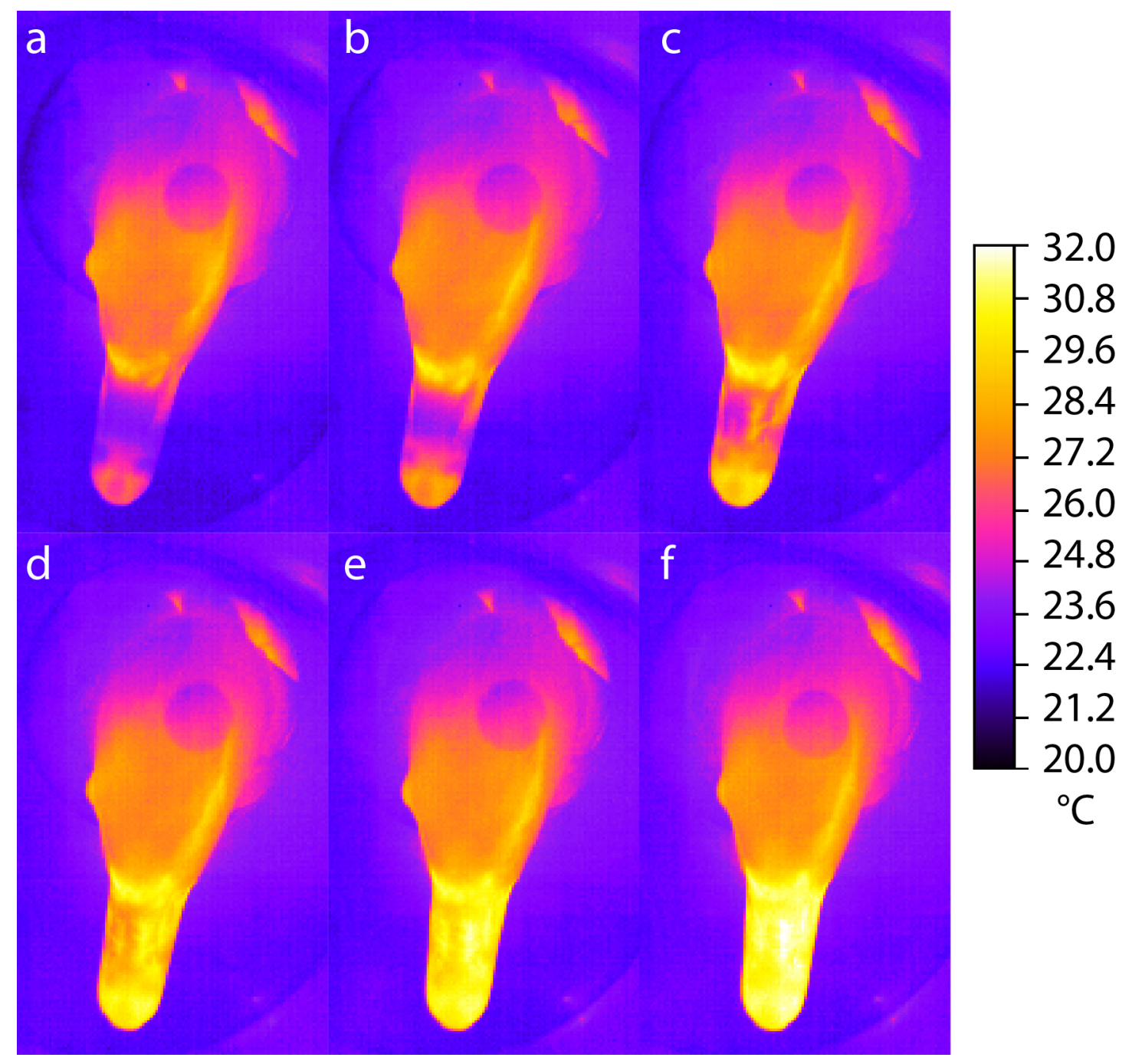

Figure 4. 


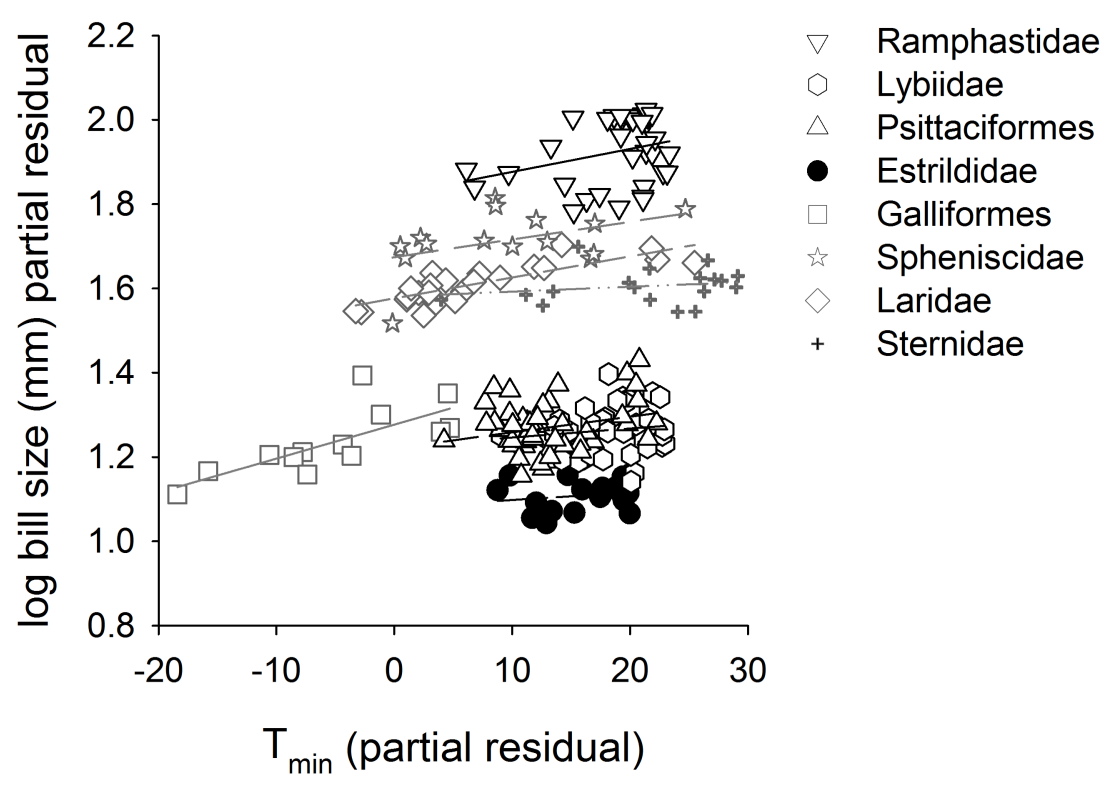

Figure 5. 

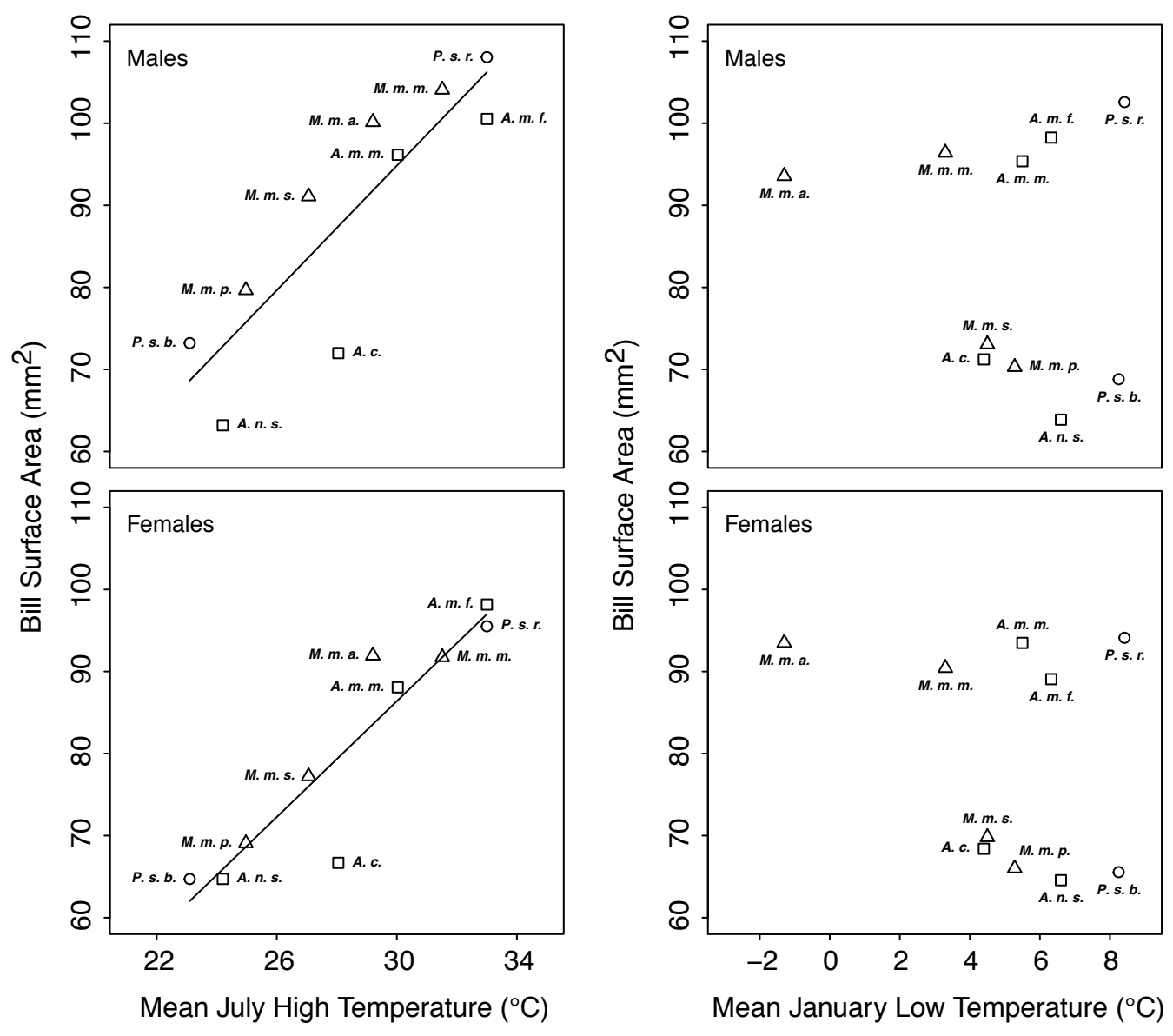

Figure 6. 
(a)

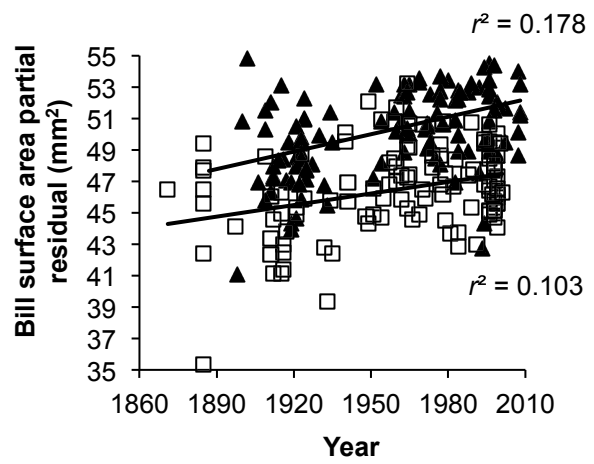

(b)

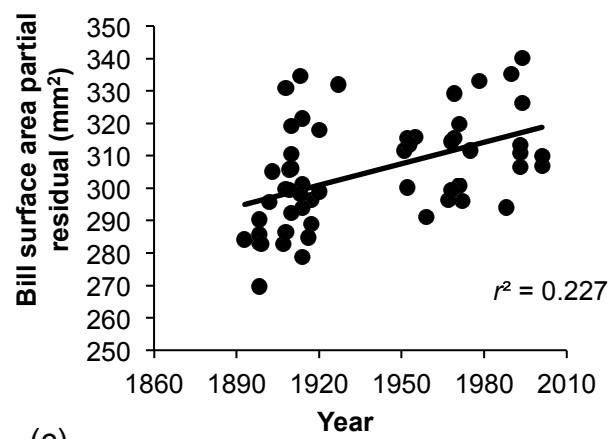

(c)

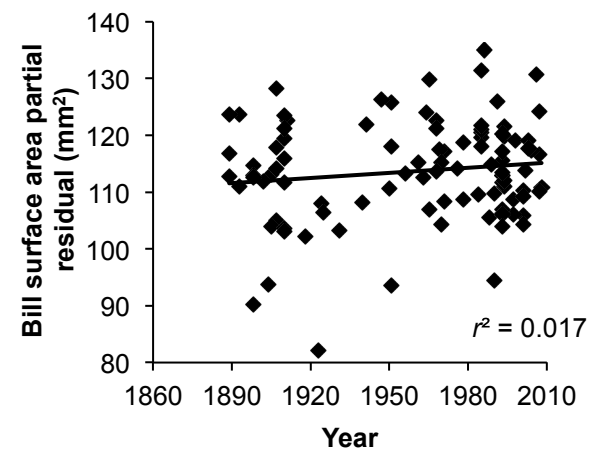

Figure 7. 


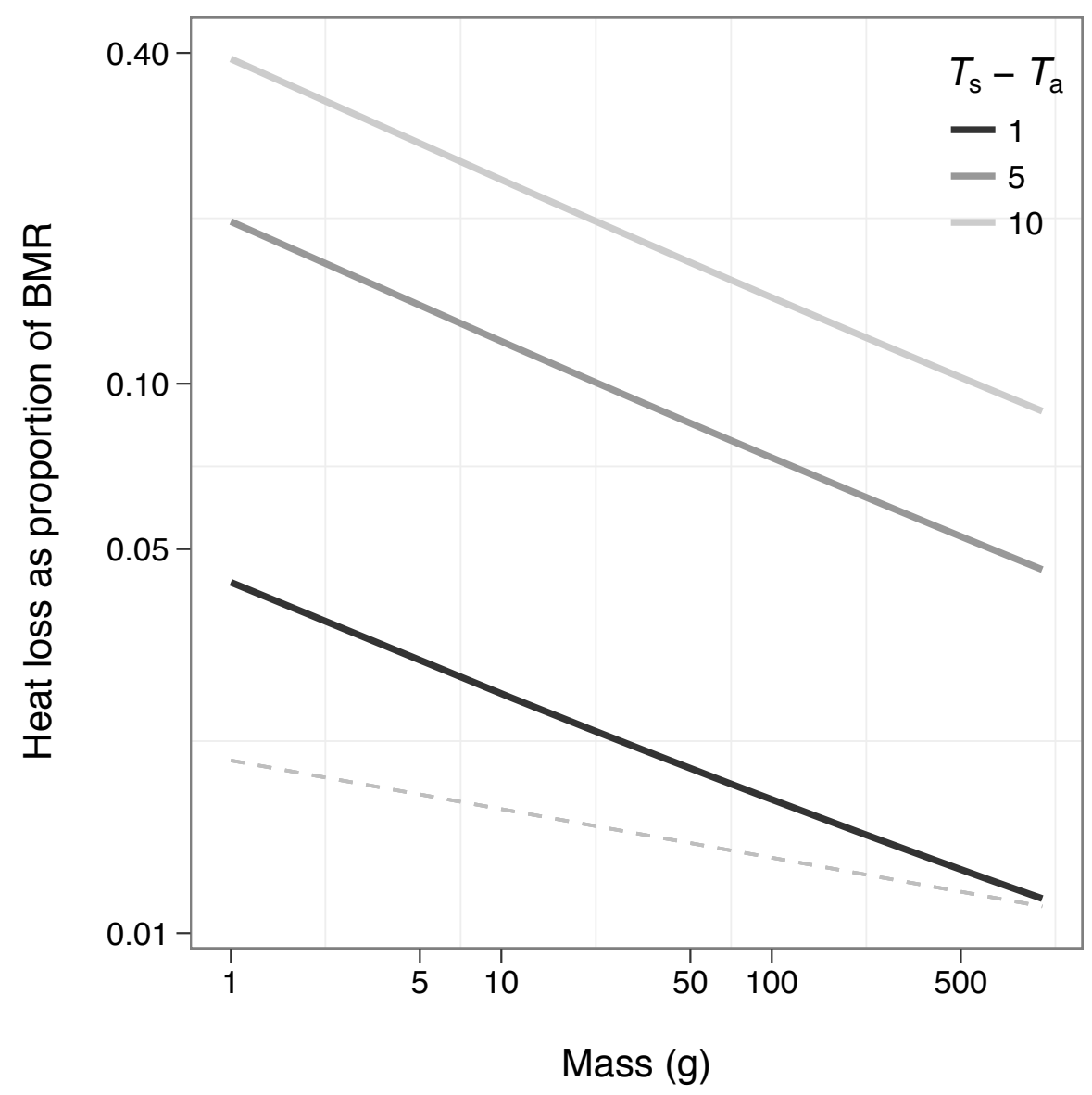

Figure 8. 